
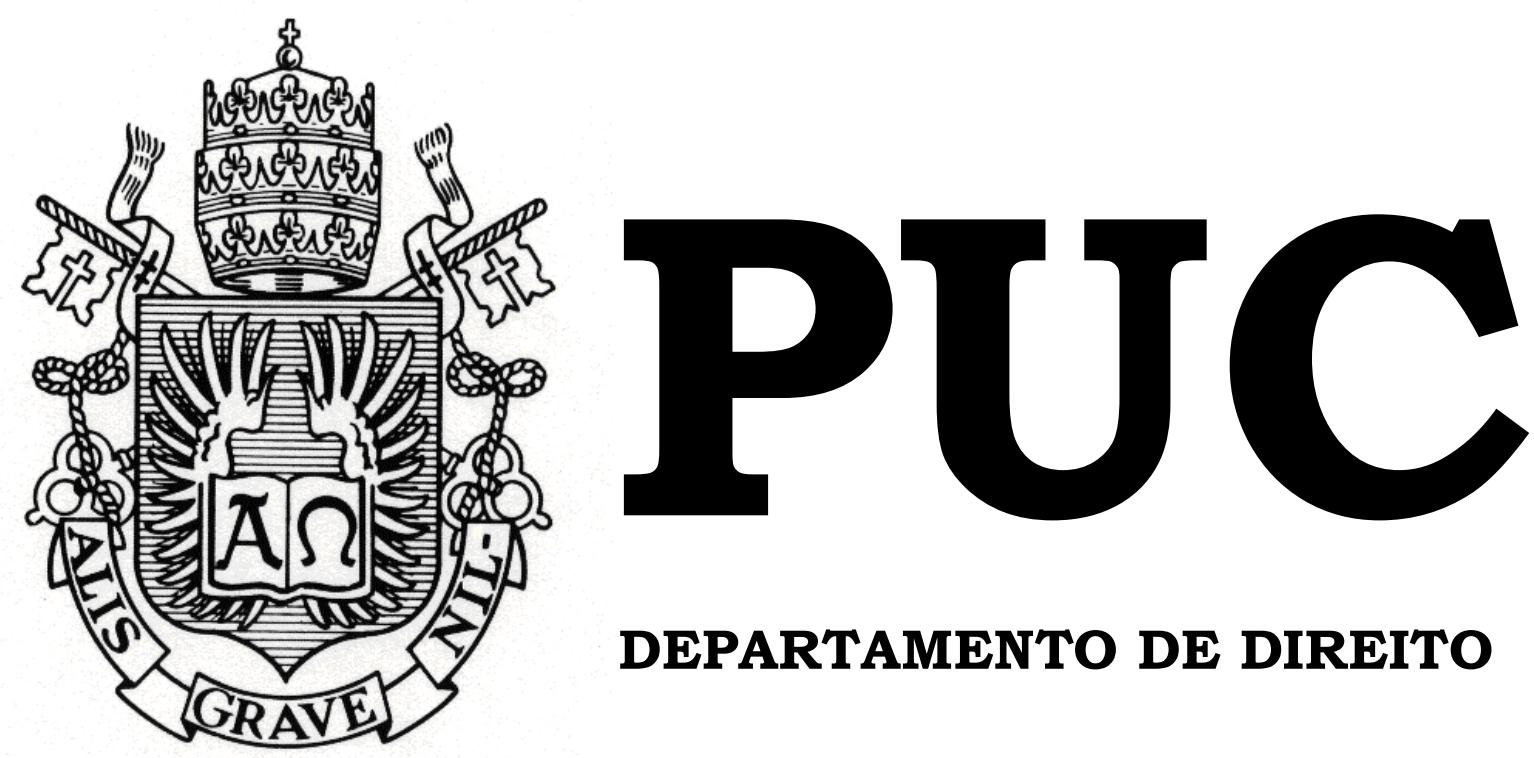

DEPARTAMENTO DE DIREITO

\title{
IMPRENSA E ORGANIZAÇÃO DO PODER POLÍTICO NO BRASIL HOJE
}

Por

THIAGO DANTAS CUNHA NOGUEIRA DE SOUZA

ORIENTADORA: REGINA COELI LISBOA SOARES

\section{1}

PONTIFÍCIA UNIVERSIDADE CATÓLICA DO RIO DE JANEIRO

RUA MARQUÊS DE SÃO VICENTE, 225 - CEP 22451-900

RIO DE JANEIRO - BRASIL 


\section{IMPRENSA E ORGANIZAÇÃO DO PODER POLÍTICO NO BRASIL HOJE}

por

THIAGO DANTAS CUNHA NOGUEIRA DE SOUZA

Monografia apresentada ao

Departamento de Direito da

Pontificia Universidade Católica do

Rio de Janeiro (PUC-Rio) para a obtenção do Título de Bacharel em Direito.

Orientadora: Regina Coeli Lisboa Soares 


\section{DEDICATÓRIA}

Dedico aos que me acompanharam nessa jornada de 5 anos, de muito aprendizado, luta, conhecimento, $e$ também, por que não, diversão, pois sem o humor não há vida que resista.

Gostaria de homenagear meus pais, Andrea $e$ Joarene, pois parceria, tal a qual recebo de vocês, é inimaginável. Sem vocês nada disso teria sido possível, sendo certo que nos momentos de maior dificuldade, quando vemos quem está do nosso lado, sempre enxerguei vocês, junto da minha irmã, Maria Eduarda.

Gostaria de enaltecer Regina, minha amiga, que desde pequeno esteve ao meu lado, de forma que não sei o que seria da minha vida sem você. Se sou alguém hoje, com toda certeza você fez parte disso.

Igualmente importante foi minha namorada, Beatriz, por ser figura de carinho sem igual, sempre com um abraço confortante nos momentos de maior ansiedade e nervosismo.

Por fim, reconheço e dedico também o presente trabalho à importância da minha Tia Mercês e do meu Tio Marcelo que, cada um a sua forma, se fizeram presente na minha vida e me ajudaram a chegar nesse momento.

Muito obrigado a todos! 


\section{AGRADECIMENTOS}

Gostaria de engrandecer a ajuda prestada pela minha orientadora Regina Coeli, pois sem ela esse trabalho não teria sido tão gratificante. Obrigado por estimular meus pensamentos desde o primeiro momento e sempre estar aberta para ouvir, qualidade tão rara nos dias atuais.

Também importante foram os grandes companheiros que fiz nessa jornada de 5 anos, que muito me ajudaram nesse trabalho, com ideias, debates, conversas, dúvidas. Nossa caminhada está apenas começando e se mantivermos essa mesma atitude não há dúvidas de que juntos cresceremos. 


\section{RESUMO}

SOUZA, Thiago Dantas Cunha Nogueira de. Imprensa e Organização do Poder Político no Brasil Hoje. Rio de Janeiro: 2017: 79 p. Trabalho de Conclusão de Curso. Departamento de Direito da Pontifícia Universidade Católica do Rio de Janeiro - PUC-Rio.

O presente trabalho possui o propósito de chamar atenção para a imprensa, a partir de sua ligação direta com o direito à informação, a liberdade de expressão, passando pela regulamentação que recebe. Diante da análise desses institutos, vê-se o quão importante é a função jornalística, de caráter fundamental para a vida em sociedade, sobretudo em tempos modernos de conteúdo amplo e superficial advindos das redes sociais. A atividade jornalística é essencial para a organização da máquina estatal, pois permite que a população tenha maior acesso aos atos de seus representantes. Nesse sentido, é preciso analisar se os veículos de comunicação veem exercendo suas prerrogativas corretamente, sendo certo que a melhor maneira de fazê-lo é a partir de casos concretos. Após esse estudo, chega-se a conclusão do quanto a mídia é importante para a democracia, e seu exercício constante por parte do povo, real detentor do poder no Brasil pósredemocratização.

Palavras-Chave: Organização do Estado; Repartição de poderes; Teoria dos freios e contrapesos; Direito à informação; Liberdade de Expressão, Liberdade de Imprensa; Cobertura da imprensa; Democracia. 


\section{SUMÁRIO}

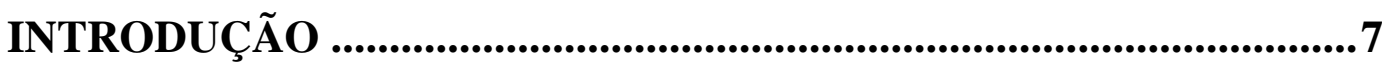

CAPÍTULO 1 - DA ORGANIZAÇÃO DO ESTADO............................11

1.1. Do Poder Constituinte Originário de 1988 ....................................... 11

1.2. Da Separação de Poderes ................................................................. 17

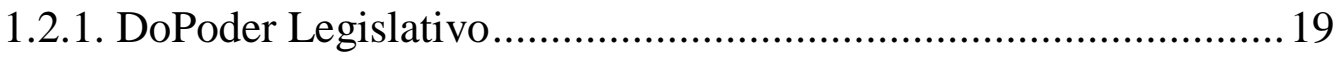

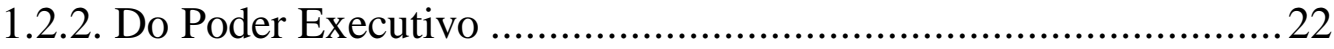

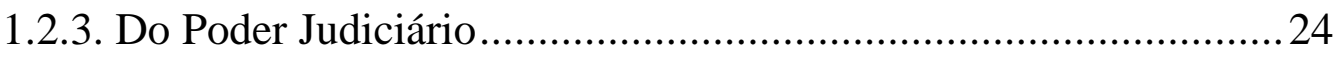

CAPITULO 2 - DO DIREITO A INFORMAR E A SER INFORMADO

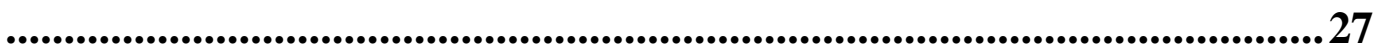

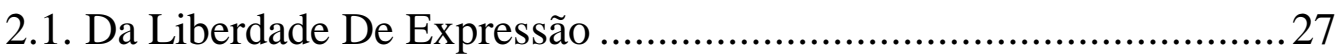

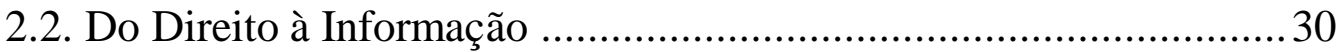

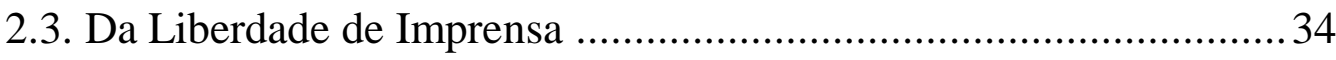

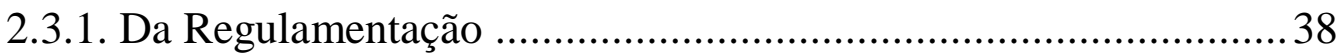

CAPÍTULO 3 - DA APLICAÇÃO CONCRETA...................................... 43

3.1. Impeachment Do Ex-Presidente Fernando Collor De Melo ..............43

3.2. Impeachment Da Ex-Presidenta Dilma Rousseff ..............................49

3.3. Da Cassação Do Mandato De Eduardo Cunha ...................................58

CAPÍTULO 4 - DA INFLUÊNCIA DA MIDIA NA ORGANIZAÇÃO

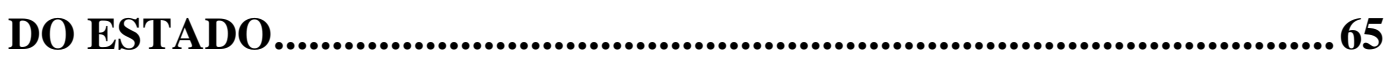

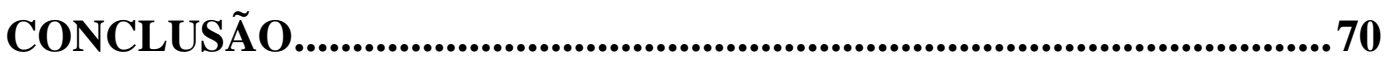

REFERÊNCIAS BIBLIOGRÁFICAS................................................73 


\section{LISTA DE ABREVIAÇÕES}

ADI -Ação Direta de Inconstitucionalidade

ADPF - Arguição de Descumprimento de Preceito Fundamental

STF - Supremo Tribunal Federal 


\section{INTRODUÇÃO}

Apesar de o jornal de papel ter sido criado no século VIII D.C. na China e o Imperador Augusto no século I ter feito a primeira publicação periódica, apenas após a criação da prensa de Gutenberg em 1440 que um algo novo surgiu, a partir da união desses dois conceitos.

O objeto utilizava o que é conhecido por tipos, que são uma quantidade considerável de pequenas peças que desenham determinadas formas na folha quando pressionados contra si. Quando organizados poderiam realizar tal procedimentos em padrão e grande quantidade, permitindo o início da circulação de periódicos, ainda que em pequena escala.

É a partir desse procedimento que surge o nome "imprensa", ainda que atualmente esse termo possua um conceito expansivo em relação ao tido quando concebido.

Contudo, apenas nos séculos XVIII e XIX, a partir da Revolução Industrial, que se inicia o processo de massificação da imprensa, com a impressão de novos jornais e periódicos. A revolução propiciou a criação de máquinas que tornavam mais fácil o processo de prensa, permitindo uma produção que atendesse a mais pessoas. Nesse período houve o maior crescimento da história dos meios de comunicação conhecidos até então. A título exemplificativo, tem-se durante esse período o surgimento de grandes marcas, como The Times (1785), The Guardian (1821) e The New York Times (1851) surgiram.

Desde então a imprensa teve sua importância crescente na sociedade, sendo certo que serviu sempre como um canal de comunicação entre os diversos setores da coletividade.

Essa significância elevou-se, chegando ao ponto em que veículos de informação passaram a exercer influência - direta ou indiretamente - sobre 
as esferas de poder e a população. Tornou-se um mecanismo de proteção da sociedade ao mesmo tempo que uma arma capaz de gerar crises que abalam as estruturas existentes.

Com o decorrer do tempo, os meios de comunicação evoluíram, de forma que o termo mais abrangente para se referir a todos esses é mídia. Essa consiste no conjunto dos diversos instrumentos de comunicação modernos, cujo fim é a transmissão de informações e conteúdos a partir do uso de diferentes plataformas - como jornais, revistas, a televisão, o rádio e a internet.

O papel desses veículos na sociedade contemporânea é sem dúvida prestigioso, garantido na norma constituinte brasileira atual em seu artigo 220. Encontra-se ainda no artigo 19 da Declaração Universal de Direitos Humanos, o qual ressalta o direito a buscar, receber e compartilhar informação, apesar de eventos recentes demonstrarem que certos preceitos dessa função são descumpridos.

A história deixa claro o valor da imprensa desde que começou a ser difundida. O jornalista imparcial, quando livre para exercer sua atividade, sempre questionou e pressionou a classe política, bem como exaltou os feitos benéficos da mesma.

Com a chegada do nazismo ao poder em 1933, Hitler criou o Ministério do Reich para Esclarecimento Popular e Propaganda, liderado por Joseph Goebbels. A intenção da pasta era expandir a mensagem nazista com sucesso através da arte, da música, do teatro, de filmes, livros, estações de rádio, materiais escolares e imprensa.

$\mathrm{Na}$ abertura dos anos de 50, Carlos Lacerda e sua Tribuna da Imprensa conseguiram mexer com a ordem do governo de Getúlio Vargas, culminando com uma crise que levou o Ex-Presidente a tirar sua própria vida. 
O regime civil-militar vivido na década seguinte com medo de reações similares impôs a censura como parte da nova ordem vigente. A imprensa com seu engajamento pró-democratização, junto aos demais setores da sociedade, garantiu que a eleição de políticos brasileiros tradicionais como Tancredo Neves e José Sarney fosse a última no Colégio Eleitoral(1985).

Diante disso, a responsabilidade dos veículos de informação é imprescindível, pois o que é nítido nessas breves linhas é a capacidade que tem de influenciar no ambiente social, político, econômico e cultural.

Dentro deste contexto, veremos que a imprensa vem atuando de maneira que merece a devida atenção no passado recente, de modo que certas análises sobre sua cobertura devem ser feitas.

Em tempos modernos, nos quais as pessoas têm acesso à notícia assim que os fatos ocorrem, a análise sobre o papel da imprensa se torna ainda mais importante. Os informes que ficam restritos às breves manchetes em que são expostos, mostram uma sociedade ávida por saber um pouco de tudo, mas que raramente se aprofunda.

Caso o jornalista não atue com os deveres que lhe são inerentes, sua atividade estará eivada de vícios onde os grandes prejudicados serão os cidadãos.

Com o intuito de elucidar a influência da imprensa na organização política do Estado brasileiro, iremos no primeiro capítulo estruturar a maneira como esse se funda dentro da ordem iniciada em 1988. Veremos quais são seus órgãos de poder e suas funções dentro da República, de maneira que possamos entender como cada um contribui para o desenvolvimento desejado pelo constituinte originário.

No segundo capítulo, iremos estudar a estrutura da imprensa, partindo do direito à informação, e passando pelos pilares da liberdade de imprensa e sua regulamentação. Nesse momento, entenderemos qual a 
importância do direito à informação dentro do Estado democrático de direito.

Conciliando essas duas exposições, no terceiro capítulo, estudaremos três casos concretos e analisaremos como se portou a imprensa, bem como as consequências disso para o povo e para a estrutura política brasileira. Restará claro como esse papel pode ser exercido de forma positiva ou negativa e como isso repercute.

No quarto capítulo concluiremos o raciocínio desenvolvido para atestarmos o poder da imprensa dentro da democracia brasileira e como suas atitudes podem causar danos na estrutura prevista na Norma Magna.

O desejo neste trabalho é ressaltar que jornalismo, liberdade e informação são pilares democráticos, capazes de influenciar políticas públicas e seu desenvolvimento.

O povo possui a capacidade de exercer pressão na sociedade, devendo receber sempre a realidade dos fatos. Esse poder estará sempre vivo onde for gerado debate, onde houver questionamento e onde estiver a informação. A imprensa é via fundamental para esse exercício por parte da população. Por essa razão o presente trabalho pretende analisar como os jornalistas veem atuando para garantir que o direito à informação seja concretizado visando o desenvolvimento da jovem democracia brasileira. 


\section{CAPÍTULO 1 - DA ORGANIZAÇÃO DO ESTADO}

\subsection{Do Poder Constituinte Originário de 1988}

Em consequência de sua rigidez, a Constituição é norma fundamental e suprema do Estado brasileiro. Toda autoridade nela encontra fundamentos, sendo certo que é quem confere poderes e competências governamentais. Também os Estados, o Distrito Federal e os Municípios, entidades da Federação, são a ela submissos, tendo em vista que se restringem - implícita ou explicitamente - pelos conceitos constantes na norma magna. O mesmo raciocínio vale, por óbvio, para os três poderes da República (Executivo, Legislativo e Judiciário) ${ }^{1}$.

Na visão de Luís Roberto Barroso, a Constituição é um sistema de normas jurídicas que institui o Estado, organiza o poder político e o seu exercício, define os direitos fundamentais das pessoas e almeja os fins públicos a serem alcançados ${ }^{2}$.

O mesmo autor nos ensina que as cláusulas pétreas têm a função de resguardar a essência da identidade original da Constituição, o núcleo de decisões políticas e de valores fundamentais que justificaram a sua criação:

\footnotetext{
Como muitas vezes registrado, as Constituições não podem aspirar à perenidade do seu texto. Se não tiverem plasticidade diante de novas realidades e demandas sociais, sucumbirão ao tempo. Por essa razão, comportam mecanismos de mudança formal e informal, pressupostos de sua continuidade histórica. Nada obstante, para que haja sentido na sua preservação, uma Constituição deverá conservar a essência de sua identidade original, o núcleo de decisões políticas e de valores fundamentais que justificaram a sua criação. Essa identidade, também referida como o espírito da Constituição, é protegida pela existência de limites materiais ao poder de reforma, previstos de modo expresso em inúmeras Cartas. São as denominadas cláusulas de intangibilidade ou cláusulas pétreas, nas quais são inscritas as matérias que ficam fora do alcance do constituinte derivado ${ }^{3}$.
}

\footnotetext{
${ }^{1}$ MENDES, Gilmar Ferreira. Curso de Direito Constitucional. São Paulo: Saraiva, 2007. p. 197.

${ }^{2}$ BARROSO, Luís Roberto. O Direito Constitucional e a Efetividade de suas Normas: Limites e Possibilidades da Constituição Brasileira. $7^{\mathrm{a}}$ ed. São Paulo: Renovar, 2003. p. 77-78.

3 BARROSO, Luís Roberto. Curso de Direito Constitucional Contemporâneo: os conceitos fundamentais e a construção do novo modelo. São Paulo: Saraiva, 2009. p. 159.
} 
Na mesma linha Paulo Bonavides aduz que a Constituição, apesar de sua supremacia, deve ser interpretada ao seu tempo, para que tenha como característica essa adaptação temporal:

A análise interpretativa da Constituição não pode, por conseguinte, prescindir do critério evolutivo, mediante o qual se explicam as transformações ocorrentes no sistema, bem como as variações de sentido que tanto se aplicam ao texto normativo, como à realidade que lhe serve de base ${ }^{4}$.

Diante da visão dos dois autores, tem-se que além de ser a norma a ser seguida pelas demais no ordenamento jurídico, a Constituição possui um texto rígido do ponto de vista formal, mas também possui certos preceitos quanto a seu conteúdo que são fundamentais para seu exercício.

Contudo, a Constituição surgiu de algum ponto, isto é, o constituinte originário possuía alguns preceitos e ideais ao elaborar a norma maior de 1988. O mesmo não simplesmente resolveu atuar e criar novas regras a serem seguidas sem motivação ou razão de ser.

Neste sentido, é necessário voltar à realidade vivida pelos brasileiros nas décadas de 1960 a 1980, na qual predominava o cenário violento em que a ditadura firmou-se. Ao ter a tortura como instrumento extremo de coerção e o extermínio o último recurso da repressão política, a ordem vigente libertou-se das amarras dos princípios da legalidade ao longo de mais de vinte anos.

O Ministro Barroso relata o infortúnio vivido nesse período da seguinte maneira:

Para registrar apenas a experiência brasileira mais recente, ao longo do regime militar:

a) na imprensa escrita, os jornais eram submetidos a censura prévia e, diante dos cortes dos censores, viam-se na contingência de deixar espaços em branco ou de publicar poesias e receitas de bolo;

b) no cinema, filmes eram proibidos, exibidos com cortes ou projetados com tarjas que perseguiam seios e órgãos genitais, transformando drama em comédia (e.g., "A Laranja Mecânica");

c) nas artes, o Balé Bolshoi foi impedido de dançar no Brasil, por constituir propaganda comunista;

\footnotetext{
${ }^{4}$ BONAVIDES, Paulo. Curso de Direito Constitucional. 15ª ed. 2014. p. 138.
} 
d) na música, havia artistas malditos, que não podiam gravar nem aparecer na TV; e outros que só conseguiam aprovar suas músicas no Departamento de Censura mediante pseudônimo;

e) na televisão, programas foram retirados do ar, suspensos ou simplesmente tiveram sua exibição vetada, em alguns casos com muitos capítulos gravados, como ocorreu com a novela Roque Santeiro.

f) o ápice do obscurantismo foi a proibição de divulgação de um surto de meningite, para não comprometer a imagem do Brasil Grande 5 .

Diante disso, era preciso criar um novo paradigma com outros princípios que protegessem o individuo e suas liberdades. Seria inimaginável que após anos em que direitos mínimos do cidadão foram desrespeitadas, o novo fundamento de validade da ordem jurídica perpetuaria essas diretrizes constrangedoras.

A Assembleia Constituinte - reunida em 1987 - criou uma nova realidade no ordenamento jurídico, tendo em vista a supremacia constitucional. Assim, devemos delimitar as características que revestiam tal órgão antes de nos debruçarmos sobre as mudanças que trouxe para o cenário político brasileiro.

Sob essa perspectiva, Gilmar Mendes relata que o poder constituinte é:

Um poder que tem na insubordinação a qualquer outro a sua própria natureza; dele se diz ser absolutamente livre, capaz de se expressar pela forma que melhor lhe convier, um poder que se funda sobre si mesmo, onímodo e incontrolável, justamente por ser anterior a toda normação e que abarca todos os demais poderes; um poder permanente e inalienável; um poder que depende apenas da sua eficácia ${ }^{6}$.

Em outras palavras, podemos dizer que é um marco inicial, pois não se funda em nenhum poder, bem como não deriva de uma ordem jurídica que lhe seja anterior. É ele que inaugura uma ordem jurídica inédita, cuja energia geradora encontra fundamento em si mesma e nada além.

\footnotetext{
${ }^{5}$ STF. MEDIDA CAUTELAR NA RECLAMAÇÃO 22.328. Relator Ministro: Luís Roberto Barroso. 20 de Novembro de 2015.

${ }^{6}$ MENDES, 2007, p. 188.
} 
É, ainda, autônomo, pois só ao poder constituinte originário cabe fixar os termos em que a nova Constituição será estabelecida e qual o Direito deverá ser implantado.

Ilimitado, tendo em vista que é soberano e não há qualquer limitação ao Direito que será implantado, exatamente pelo fato de que a este preexiste. Neste tocante, a doutrina moderna vem rejeitando esta compreensão, apesar de o Supremo Tribunal Federal já ter se manifestado a respeito ${ }^{7}$.

A primeira consequência desta interpretação em relação ao poder e seus limites - os quais segundo a corte seriam inexistentes - é a impossibilidade de seus ministros analisarem e julgarem a constitucionalidade em abstrato das normas originárias do texto constitucional vigente, uma vez que, tendo sido ela própria criada pela Constituição ${ }^{8}$ e tendo por função precípua a sua guarda, não poderia quem veio depois analisar quem a criou.

Apesar destas características, o cenário anterior de dor e sofrimento, atrelado a um desejo crescente da população por mudanças - externado pelo movimento das "Diretas Já", entre tantas outras formas de manifestação não deixou saída à Assembleia Constituinte. Desta maneira, o constituinte

\footnotetext{
${ }^{7}$ A questão já foi objeto de análise pelo STF na ADI n. 815/DF. Nesta oportunidade o Governador do Rio Grande do Sul moveu Ação Direta de Inconstitucionalidade em face de dispositivo constitucional originário, entendendo-o violador da igualdade do voto. Entendeu-se que o pedido era juridicamente impossível, tendo em vista que norma constitucional originária não poderia ser alvo de inconstitucionalidade. O Supremo Tribunal Federal baseou sua decisão afirmando que, se o próprio Tribunal recebeu seus poderes e competências por meio do poder constituinte originário, não seria possível, àquele Órgão, ir contra qualquer norma diretamente realizada pelo mesmo poder constituinte originário que o criou; Ainda acrescenta-se que não haveria como o STF exercer controle sobre o poder constituinte originário, em razão deste não fazer parte de sua competência. Portanto, o Tribunal entendeu que não existia inconstitucionalidade de norma constitucional originária. Isto evidencia que o Supremo seguiu a corrente positivista, que acredita no ilimitado Poder Constituinte Originário. Contudo, é preciso frisar que o mesmo raciocínio não é o utilizado quanto ao controle de constitucionalidade de normas constitucionais introduzidas por meio de Emendas Constitucionais, em razão de, neste caso, a norma existir por conta da atuação do Poder Constituinte Derivado Reformador.

${ }^{8}$ Constituição da República Federativa do Brasil. Título I, Dos Princípios Fundamentais. Art. 102. BRASIL. Constituição (1988). Disponível em: <http://www.planalto.gov.br/ccivil_03/constituicao/constituicao.htm>. Acesso em: 17.09. 2016.
} 
não poderia atuar de outra forma senão criando uma nova ordem jurídica fundada em preceitos de liberdade e valorização dos direitos humanos.

Ainda sobre as características do poder constituinte originário, temos que é incondicionado, porque não se sujeita a nenhum processo ou procedimento prefixado para a sua manifestação. Pode agir livremente, sem condições ou formas pré-estabelecidas, pois não está condicionado a nenhuma fórmula prefixada.

A partir dessas premissas, o país, aos 05 dias do mês de outubro do ano de 1988, deu início a uma nova fase. Daquele momento em diante, direitos fundamentais passaram a ser protegidos de maneira expressa, sendo certo que se expandiu a visão de que a Constituição é o local adequado para positivar as normas asseguradoras dessas pretensões. Tal pensamento resta ainda mais nítido ao se verificar que estes direitos de extrema importância viraram cláusulas pétreas.

A relevância da proclamação dos direitos fundamentais pode ser sentida de imediato a partir da leitura do Preâmbulo da atual Constituição, o qual deixa cristalino o intuito de consagrar um Estado Democrático, cujo objetivo primário é o de amparar o exercício dos direitos sociais e individuais, a liberdade, a segurança, o bem-estar, o desenvolvimento, a igualdade e a justiça como diretrizes de uma sociedade fraterna, pluralista e sem preconceitos, fundada na harmonia social e comprometida, na ordem interna e internacional, com a solução pacífica das controvérsias.

Neste sentido, temos diversos direitos sociais e individuais sendo contemplados, como a educação, a vida, a liberdade, a igualdade, a segurança, a propriedade, a saúde, a alimentação, o trabalho, a moradia, o transporte, o lazer, a segurança, a previdência social, a proteção à maternidade e à infância, a assistência aos desamparados e o direito à informação, objeto do desenvolvimento do presente trabalho.

José Afonso da Silva expõe seu pensamento sobre a Constituinte de 1988: 
O país que a Constituinte desenhou é aquele plasmado na Constituição que tem propiciado a melhoria das condições de vida da população. Se você quer saber se hoje o país é melhor do que antes da Constituinte, por certo que a resposta é positiva, porque o Brasil hoje é muito melhor do que era antes. Falta ainda muita coisa para o país ficar ainda melhor, porque as promessas da Constituição no sentido da realização mais efetiva dos direitos sociais ainda não foram cumpridas, mas a Constituição dá o instrumental para isso e, na medida em que ela está propiciando um regime democrático de plena liberdade, podemos ter a esperança de que virão dias melhores mediante políticas públicas adequadas para a melhoria das condições sociais do povo 9 .

Contudo, para que tudo isso seja possível, o constituinte originário necessitava organizar o Estado de forma que o mesmo trabalhasse em conjunto e organizadamente. A mera apresentação dos desejos que tinha para a sociedade de nada bastaria sem a exposição dos meios para atingir tais fins. Conforme exposto acima - nas palavras do autor - era necessário que a Constituição desses meios para que os ideais que planejava fossem alcançados.

A percepção acerca da relação entre o constitucionalismo dentro de um Estado Democrático de Direito e a correspondência com a democracia participativa por meio dos direitos fundamentais individuais implicam em conceituar tais institutos para estruturar um entendimento sólido. Dessa forma, a democracia e a jurisdição constitucional também precisam ser definidas e isso significa afirmar que, enquanto a Constituição é o fundamento de validade (superior) do ordenamento e geradora da própria atividade político-estatal, a jurisdição constitucional passa a ser a condição de possibilidade do Estado Democrático de Direito ${ }^{10}$.

O termo Estado de Direito foi substituído por Estado Democrático de Direito, incorporado na Constituição Federal de 1988 como o garantidor do efetivo exercício dos direitos civis, sociais, políticos, entre outros. Está expresso no Preâmbulo e definido pelo Artigo $1^{\circ}$, ligado ao princípio da legalidade e concretiza o princípio da igualdade, é o núcleo-base em que se

\footnotetext{
${ }^{9}$ SENADO. Disponível em:

<http://www12.senado.leg.br/noticias/materias/2008/08/08/jose-afonso-da-silva-o-maisdramatico-na-constituinte-foi-a-rebeliao-dos-conservadores>. Acesso em: 17 09. 2016.

${ }^{10}$ STRECK, Lenio Luiz. Jurisdição Constitucional e Decisão jurídica. $3^{\mathrm{a}}$ ed. São Paulo: Revista dos Tribunais, 2013. p. 37.
} 
acoplam a democracia e os direitos humanos fundamentais conquistados ${ }^{1112}$.

Deste modo, o Estado Democrático de Direito possui como objetivo permitir que o Estado garanta as liberdades civis e os direitos e garantias fundamentais, através da proteção jurídica estabelecida, sendo certo que o Estado brasileiro atua a partir do princípio da divisão de poderes como uma maneira de atingir estes fins.

\subsection{Da Separação de Poderes}

Neste contexto, $\mathrm{o}$ art. $2^{\circ}$ frisa que são poderes da União, independentes e harmônicos, o Legislativo, o Judiciário e o Executivo. A estes órgãos, a Constituição Federal brindou com sua autoridade soberana do Estado, lhes garantindo autonomia e independência a partir de um trabalho conjunto ${ }^{13}$.

Com respeito à independência dos poderes consagrados pela Constituição Federal Brasileira, devemos elucidar certos pontos a respeito do tema.

Inicialmente, temos que a independência entre poderes significa: i) que a entrança e a continuidade de pessoas em um órgão do governo independem da confiança ou da vontade dos outros; ii) que os titulares no exercício de suas atribuições não necessitam de consulta ou autorização prévia; iii) que, se auto-organizam, nos termos da lei. A título meramente exemplificativo, podemos dizer que ao Presidente da República cabe prover e extinguir cargos públicos da Administração federal, bem como exonerar ou demitir quem os ocupa, enquanto é da competência do Congresso Nacional ou dos Tribunais prover os cargos dos respectivos serviços

${ }^{11}$ Constituição da República Federativa do Brasil. Título I, Dos Princípios Fundamentais, Art. $1^{\circ}$. BRASIL. Constituição (1988). Acesso em: 20 09. 2016.

${ }^{12}$ CANOTILHO, J. J. Gomes et al.. (Org.). Comentários à Constituição do Brasil. São Paulo: Saraiva/Almedina, 2013. p. 116.

${ }^{13}$ Constituição da República Federativa do Brasil. Título I, Dos Princípios Fundamentais. Art. $2^{\circ}$. BRASIL. Constituição (1988). Acesso em: 20.09.2016. 
administrativos, exonerar ou demitir seus ocupantes; às Câmaras do Congresso e aos Tribunais concerne elaborar os respectivos regimentos internos, sua organização, direção e polícia, ao passo que ao Chefe do Executivo incumbe a organização da Administração Pública, estabelecer seus regimentos e regulamentos. Agora, a independência e autonomia do Poder Judiciário se tornaram ainda mais pronunciadas, pois passou para a sua competência também a nomeação dos juízes e outras providências referentes à sua estrutura e funcionamento, inclusive em matéria orçamentária $^{14}$.

A harmonia entre os poderes é notada de plano a partir das normas de cortesia no trato recíproco e no respeito às prerrogativas e faculdades a que mutuamente todos têm direito.

Ainda convém asseverar que nem a independência, nem a divisão de tarefas designadas aos órgãos são absolutas. Há interferências que visam o estabelecimento de um sistema de freios e contrapesos para evitar o arbítrio e o desmando de um em detrimento do outro e especialmente dos governados, na busca de estabilidade para a realização do bem à coletividade, sendo isso indispensável. Isto significa que se pode verificar em diversos momentos que um dos poderes estará exercendo funções que em um primeiro momento seria do outro.

Pedro Abramovay explica o conceito contemporâneo da separação de poderes de maneira clara:

A relação entre os Poderes não pode ser vista como fruto de atribuições expressas, predefinidas e impermeáveis. A única maneira de o princípio da separação de Poderes conviver com a Democracia e exercer a sua principal função de combater o arbítrio é a de um permanente ambiente de diálogo constitucional $(\ldots)^{15}$.

14 SILVA, José Afonso da. Curso de Direito Constitucional Positivo. 22a ed. São Paulo: Malheiros, 2003. p. 112.

15 ABRAMOVAY, Pedro. Separação de Poderes e Medidas Provisórias. Rio de Janeiro: Elsevier, 2012. p. 32. 
Novamente, cabe exemplificar no intuito de esclarecer. Inicialmente, pensamos a elaboração de normas como função típica legislativa. Contudo, o presidente pode editar Medidas Provisórias, conforme o artigo 62 da Constituição Federal, exercendo uma atividade que a priori não seria sua, mas sim da Câmara dos Deputados e do Senado Federal.

Outro caso ocorre quando o Congresso Nacional - cada casa em seu devido momento - julga os crimes de responsabilidade do Presidente da República, conforme preceitua o artigo 86 da Carta Magna. Esta, a princípio, seria atividade do Poder Judiciário, contudo, aqui quem a realiza é o Congresso Nacional, a partir do devido processo legal, cabendo uma interferência do Judiciário, caso este não seja respeitado.

Portanto, os chamados três poderes em diversos momentos se relacionam, assumindo competências que inicialmente não seriam suas, mas diante da busca por um equilíbrio entre os mesmos, se faz necessário, e até mesmo saudável, para que - ao menos em tese - não ocorra o avanço de um sobre o outro.

A partir desta exposição, e tendo como claras as intenções do constituinte originário, e a partir de alguns dos conceitos basilares da organização do Estado, veremos as funções de cada um destes poderes para entendermos como colaboram uns com os outros para atingir as metas definidas pelo constituinte originário.

\subsubsection{DoPoder Legislativo}

A função legislativa - da União - faz-se por meio do trabalho do Congresso Nacional e de suas Casas (Câmara dos Deputados e Senado, as quais são compostas, respectivamente por Deputados e Senadores). 
A tradição brasileira, desde o Império - com exceção às Constituições de 1934 e 1937 - é de ter duas casas para organizar esta função de poder, tratando-se, portanto, do sistema bicameral ${ }^{16}$.

A Câmara dos Deputados é composta pelos representantes do povo, eleitos conforme o sistema proporcional, em cada Estado e no Distrito Federal, com mandato de 4 anos, consoante os artigos 44 e 45 da Constituição Federal.

Enquanto o Senado é a Casa dos Estados, sendo composto por três representantes de cada um deles e do Distrito Federal, eleitos pelo voto majoritário, com mandato de 8 anos ${ }^{17}$.

Acerca destes, é importante frisar que não há preponderância de um sobre o outro, apesar de a Câmara, formalmente, gozar de certa primazia, tendo em vista que é nela que o Presidente da República, o Supremo Tribunal Federal, os Tribunais Superiores e os cidadãos apresentam seus projetos para a elaboração de leis, consoante o artigo $61, \S 2^{\circ}$, e 64 , da Constituição Federal.

A função precípua do Congresso Nacional é a de edição de atos normativos primários, que instituem direitos e criam obrigações. Neste sentido, a Constituição Federal em seu artigo 59 traz a lista de instrumentos normativos possíveis de serem feitos para atender a tais fins. São estes: Emenda Constitucional, Leis Complementares, Leis Ordinárias, Leis Delegadas, Decretos Legislativos e Resoluções ${ }^{18}$. A exceção, no caso, são as Medidas Provisórias, que derivam de ato do Presidente da República e não do procedimento realizado no Congresso Nacional.

Diante de tais competências, Gilmar Mendes afirma:

\footnotetext{
16 SILVA, 2003, p. 511.

17 Constituição da República Federativa do Brasil. Art. 52, I e II.

BRASIL. Constituição (1988). Acesso em: 20.09.2016.

18 MENDES, 2007, p. 873.
} 
O conjunto de atos que uma proposição normativa deve cumprir para se tornar uma norma de direito forma o processo legislativo, que é objeto de regulação na Constituição e por atos internos no âmbito do Congresso Nacional ${ }^{19}$.

Consoante este entendimento, revela-se que a face da função legislativa exercida pelo Congresso Nacional vai além da mera elaboração de normas, tendo também a função de modificá-las e revogá-las dentro de um processo inteiramente sistemático em validação de seus atos tal como estabelece a Carta Magna para que se revista de constitucionalidade e validade de seus efeitos, equilibrando-os com o momento vivido pelos cidadãos em sociedade.

José Afonso da Silva ainda acrescenta três grupos de atividades realizadas por esta esfera de Poder, que são:

i) atribuição deliberativa, que envolve a prática de atos concretos, de resoluções referendárias, de autorizações, de aprovações, de fixação de situações e de julgamentos técnicos, consignado no artigo 49 da Carta Magna, o que é feito por meio de decreto legislativo ou por resoluções, seguindo as regras regimentais, e sem qualquer interferência de caracterizando função exclusiva do Congresso;

ii) atribuições de fiscalização e controle, exercido por meio de diversos procedimentos, como por exemplo, o controle externo feito pelo Congresso Nacional e exercido com auxílio do Tribunal de Contas da União (TCU), com observância ao disposto no art. 70 da Constituição Federal, à legalidade, legitimidade, economicidade, aplicação das subvenções e renúncia de receitas.

O Tribunal de Contas da União exercerá essa função em auxílio ao Congresso Nacional - segundo o art. 71, II, da Constituição Federal - a partir da análise das contas dos administradores, bem como a responsabilidade destes sobre os bens públicos. No entanto, Gilmar Mendes observa que estas atividades não obstam a revisão das decisões por meio do

\footnotetext{
19 Ibid., 2007, p. 873.
} 
Poder Judiciário, assim como não fazem coisa julgada; apenas não poderão ser discutidas posteriormente em sede judicial as questões que imputem débitos ou multas que se constituam em títulos executivos extrajudiciais executados por meio da Advocacia Geral da União.

Quanto a estas atividades, a doutrina de Gilmar Mendes elucida o tema a respeito da fiscalização e do controle:

No desempenho da sua função fiscalizadora, o Congresso Nacional pode desejar acompanhar de perto o que acontece no governo do País. Para isso, a Câmara dos Deputados, o Senado e qualquer das Comissões dessas Casas estão aptos para convocar Ministros da República ou titulares de órgãos diretamente subordinados à Presidência da República, para que prestem, pessoalmente, informações sobre assunto previamente estabelecido, podendo, se o Legislativo o preferir, deles requerer informações por escrito. Configura crime de responsabilidade o desatendimento a esses chamados ${ }^{20}$.

Ainda sobre esta função de fiscalização realizada pelo Congresso Nacional, podemos destacar a criação de Comissões Parlamentares de Inquérito para apuração de fato determinado a partir do cumprimento das formalidades específicas (art. $158, \S 3^{\circ}$, da CF).

iii) Atribuição de julgamento de crimes de responsabilidade do Presidente da República, dos Ministros de Estado, dos Ministros do Supremo Tribunal Federal, dos membros do Conselho Nacional de Justiça e do Conselho Nacional do Ministério Público, do Procurador-Geral da República e do Advogado-Geral da União ${ }^{21}$.

Desta forma, resta claro que o Poder Legislativo realiza, além de tarefas relacionadas à função legislativa propriamente dita, outras exigidas pela teoria dos freios e contrapesos.

\subsubsection{Do Poder Executivo}

20 MENDES, 2007, p. 857.

21 SILVA, 2003, p. 523. 
De modo geral, pode-se dizer que o Poder Executivo é o órgão constitucional cuja função é a de praticar atos de Chefia de Estado e de Chefia de Governo e de Administração ${ }^{22}$. Devemos tratar disso de maneira abstrata, pois o constituinte não delimitou precisamente seu conteúdo, ora tratando-o a partir de sua função, ora a partir do órgão (cargo e ocupante, art. $\left.2^{\circ}\right)$.

A Constituição estabelece que o Poder Executivo é exercido pelo Presidente da República, que contará com o auxílio dos Ministros de Estado, consoante o art. 76. Logo, institui-se no Brasil o sistema presidencialista, no qual as funções de Chefe de Governo e Chefe de Estado cabem a uma única pessoa.

Importante frisar que neste sistema não há necessidade de aprovação do Congresso para que se ocupe tal cargo, sendo apenas necessário que se cumpra os requisitos constitucionais, entre os quais está alcançar a maioria dos votos válidos nas urnas para um mandato de 4 anos com direito a uma reeleição $0^{23}$.

Ainda sobre o sistema de governo, ao trabalho que se pretende desenvolver é fundamental ressaltar que foi uma escolha da população brasileira, que, no ano de 1993, recusou, em Plebiscito, adotar o sistema parlamentarista, no qual as funções de Chefe de Estado e Chefe de Governo são exercidas por pessoas distintas.

Ao Presidente cabem, entre outras funções, algumas que merecem o devido destaque, como, por exemplo, a de direção da Administração Federal, nomeando e exonerando Ministros de Estado, tal qual o faz com relação ao Advogado-Geral da União e o Presidente do Banco do Brasil (este após aprovação pelo Senado). E também expede decretos regulamentadores para a fiel execução da lei $^{24}$.

\footnotetext{
22 Ibid., p. 544.

23 Constituição da República Federativa do Brasil. Art. 77. BRASIL. Constituição (1988). Acesso em: 20.09.2016

24 Constituição da República Federativa do Brasil. Art. 84.
} 
Ainda cabe a ele sancionar, vetar, promulgar e publicar as leis, participando ativamente do processo legislativo na parte que lhe cabe, sendo certo que possui direito de peticionar pedindo que seja feito o controle abstrato de leis que julgue inconstitucional, por ser um dos legitimados ativos para a propositura de tal ação ${ }^{25}$.

Ademais, pode editar Medidas Provisórias, com força de lei, para serem aprovadas pelo Congresso Nacional no prazo de 60 dias, desde que fundadas nos pressupostos de urgência e relevância ${ }^{26}$.

Entende-se por urgente aquilo em que a abstenção levará a um dano irreparável ou de difícil reparação, não podendo ser adiada. Nesse sentido assevera Celso Antônio Bandeira de Mello:

(...) mesmo que a palavra contenha em si algum teor de fluidez, qualquer pessoa entenderá que só é urgente o que tem de ser enfrentado imediatamente, o que não pode aguardar o decurso do tempo, caso contrário o benefício pretendido inalcançável ou o dano que se quer evitar consumar-se-á ou, no mínimo existirão sérios riscos de que sobrevenha efeitos desastrosos em caso de demora ${ }^{27}$.

Resta claro, assim, que a função precípua inerente ao poder Executivo, qual seja governar e administrar o Estado, através da observação das regras emanadas da Constituição e das Leis ${ }^{28}$, não raras vezes excursiona nos campos de atuação de outra esfera de poder, como por exemplo, no caso citado referente às Medidas Provisórias.

\subsubsection{Do Poder Judiciário}

Organizado entre os artigos 92 a 126 da Constituição Federal, o Poder Judiciário é composto por órgãos cuja função é a de compor conflitos de interesses nos casos concretos que se apresentam a ele.

\footnotetext{
BRASIL. Constituição (1988). Acesso em: 23.09.2016.

25 Ibid., Art. 103.

26 Ibid., Art. 62.

${ }^{27}$ MELLO, Celso Antônio Bandeira de. Curso de Direito Administrativo. 20a ed. São Paulo-SP: Editora Malheiros, 2006. p. 118.

28 Constituição da República Federativa do Brasil. Art. 78.

BRASIL. Constituição (1988). Acesso em: 23.09.2016.
} 
A Constituição de 1988 inaugurou uma nova fase no que diz respeito à função do Poder Judiciário, pois lhe conferiu autonomia institucional ${ }^{29}$.

Para solucionar os conflitos que a ele chegam, devem ser observados certos critérios objetivos, sob pena de se criar juízos de exceção, com critérios particulares, privados e próprios, como já observados em outros períodos da história ${ }^{30}$.

Cabe ao Poder Judiciário aplicar o direito existente para a solução das lides. Enquanto a lei tem um caráter abstrato e genérico, o ato jurisdicional terá seus sujeitos delimitados, e mesmo que seja uma decisão erga omnes o Poder Judiciário deve ser provocado, sob pena da violação da inércia que lhe é característica, tirando algumas poucas exceções que fogem à regra.

Uma garantia que deve ser observada é a prevista no artigo $5^{\circ}$, XXXV, que expressa o princípio da inafastabilidade da jurisdição, no intuito de garantir direitos a todos igualmente.

Importante frisar que a organização do Judiciário é fundamental para a autonomia já citada, pois é ele que realiza esse autocontrole. Fosse um outro poder a fazê-lo, poderia gerar uma sujeição inadmissível, que feriria a separação de poderes.

Gilmar Mendes esclarece:

A Constituição de 1988 dotou os tribunais de um poder de autogoverno consistente na eleição de seus órgãos diretivos, elaboração de seus regimentos internos, organização de suas secretarias e serviços auxiliares e os dos juízos que lhe foram vinculados, no provimento de cargos de magistrados de carreira da respectiva jurisdição, bem como no provimento de cargos necessários à Administração da Justiça (CF, art. 96, I) ${ }^{31}$.

A partir dessa independência é possível que o Poder Judiciário exerça suas atribuições, não havendo consequências se tomar medidas que

\footnotetext{
29 MENDES, 2007, p. 931.

30 SILVA, 2003, p. 555-556.

31 BRASIL. Constituição (1988). Acesso em: 23.09.2016
} 
contrariem interesses alheios, ao contrário do que ocorreria se dependesse de uma autorização do Congresso Nacional para se organizar, por exemplo.

Contudo, em mais uma mostra da relação constante que existe entre as esferas de Poder, há que se analisar o processo de escolha dos Ministros do Supremo Tribunal Federal.

Esse se compõe de onze Ministros, escolhidos dentre brasileiros natos, no gozo de seus direitos políticos, com mais de trinta e cinco anos e menos de sessenta e cinco anos de idade, notável saber jurídico e reputação ilibada, escolhidos e nomeados pelo Presidente da República depois de aprovada a escolha pela maioria absoluta do Senado Federal ${ }^{32}$.

Conforme o comando exposto, é preciso que dois outros poderes se manifestem para que se escolha um novo ministro, restando claro que mais uma vez é fundamental o trabalho harmonioso de todos.

No tocante às competências desta corte, merece destaque a da guarda da constituição. Neste sentido, devemos novamente asseverar que a Constituição precisa ser entendida em sentido lato, ou seja, não só o conjunto dos 250 artigos nela presentes, mas sim de todo o bloco de constitucionalidade existente, aumentando sua possibilidade de aplicação.

É relevante atentar-se para o fato de que não só o Supremo Tribunal Federal, mas todos os órgãos do poder Judiciário devem procurar por meio de suas atuações atingir os fins que o constituinte definiu, respeitando os próprios limites constitucionais, sob pena de interferência na organização do Estado.

32 Constituição da República Federativa do Brasil. Art. 101. Ibid., Acesso em: 23.09.2016. 


\section{CAPITULO 2 - DO DIREITO A INFORMAR E A SER INFORMADO}

\subsection{Da Liberdade De Expressão}

A liberdade de expressão e a dignidade da pessoa humana são dois conceitos diretamente relacionados, não apenas por serem fundamentais no ordenamento jurídico pátrio, mas também pelo fato de que não existe concepção de vida digna onde não exista liberdade para exprimir desejos e conviç̧ões.

Ademais, é inerente ao Estado Democrático de Direito o poder de se manifestar. Essa voz que todos do povo possuem permite o controle de órgãos, representantes, atividade e afins, de forma que a fiscalização se torna efetiva, podendo-se considerá-la conditio sine qua non do Estado Democrático de Direito ${ }^{33}$.

Por essas e outras razões, a liberdade de expressão foi tutelada na Constituição Federal, garantindo a livre expressão da atividade intelectual, artística, científica e de comunicação, independentemente de censura ou licença ${ }^{34}$.

\section{Para Nuno e Sousa:}

A liberdade de expressão consiste no direito à livre comunicação espiritual, no direito de fazer conhecer aos outros o próprio pensamento (na fórmula do art. $11^{\circ}$ da Declaração francesa dos direitos do homem de 1989: a livre comunicação de pensamentos e opiniões). Não se trata de proteger o homem isolado, mas as relações interindividuais ('divulgar'). Abrange-se todas as expressões que influenciam a formação de opiniões: não só a própria opinião, de caráter mais ou menos crítico, referida ou não a aspectos de verdade, mas também a comunicação de factos (informações) ${ }^{35}$.

\footnotetext{
33 SARLET, Ingo Wolfgang. A eficácia dos direitos fundamentais. $6^{\mathrm{a}}$ ed. Porto Alegre: Livraria do Advogado, 2006. p. 71.

34 Constituição da República Federativa do Brasil. Art. 5, IX.

BRASIL. Constituição (1988). Acesso em: 01.12.2016.

35 SOUSA, Nuno e. A liberdade de imprensa. Coimbra: Coimbra, 1984. p. 137.
} 
A liberdade de expressão caracteriza a busca dos indivíduos por melhoras nos mais diversos campos da sociedade. Feliz é o povo que atualmente consegue usufruir desse direito sem ter que temer consequências arbitrárias, tendo em vista diversos foram os que sofreram, e sofrem, ao tentar revelar os lados obscuros dos centros de poder.

No entanto, essa ainda deve ser entendida como o poder de se manifestar sobre os fatos sem qualquer vedação a priori, sendo certo que caso se constate posteriormente violações ao direito de terceiro, esse poderá buscar a tutela jurisdicional para se ver ressarcido do dano sofrido, tendo em vista que tal direito não é ilimitado.

É exatamente sobre isso que a Declaração dos Direitos do Homem e do Cidadão em seu artigo $4^{\circ}$ trata:

A liberdade consiste em poder fazer tudo aquilo que não prejudique outrem: assim, o exercício dos direitos naturais de cada homem não tem por limites senão os que asseguram aos outros membros da sociedade o gozo dos mesmos direitos. Estes limites apenas podem ser determinados pela $\mathrm{Lei}^{36}$.

A liberdade de expressão, tal qual qualquer outro direito não é absoluta e não pode ser levada dessa forma. É preciso que haja prudência, assim como em qualquer outro campo da vida. É exatamente isso que Bernardo Gonçalves Fernandes ensina:

\begin{abstract}
Nesses termos, para a doutrina dominante, falar em direito de expressão ou de pensamento não é falar em direito absoluto de dizer tudo aquilo ou fazer tudo aquilo que se quer. De modo lógico-implícito a proteção constitucional não se estende à ação violenta. Nesse sentido, para a corrente majoritária de viés axiológico, a liberdade de manifestação é limitada por outros direitos e garantias fundamentais como a vida, a integridade física, a liberdade de locomoção. Assim sendo, embora haja liberdade de manifestação, essa não pode ser usada para manifestação que venham a desenvolver atividades ou práticas ilícitas (antissemitismo, apologia ao crime etc...) ${ }^{37}$.
\end{abstract}

\footnotetext{
36 Declaração dos Direitos do Homem e do Cidadão. art. 4º. França, 1789. Disponível em: $<$ http://pfdc.pgr.mpf.mp.br/atuacao-e-conteudos-de-apoio/legislacao/direitoshumanos/declar_dir_homem_cidadao.pdf>. Acesso em: 01.12.2016.

37 FERNANDES, Bernardo Gonçalves. Curso de Direito Constitucional. $3^{\mathrm{a}}$ ed. Rio de Janeiro: Lumen Juris, 2011. p. 279.
} 
Da mesma linha a lição de Fábio Carvalho Leite:

A restrição imposta pelo Poder Judiciário, no entanto, não é compreendida como um problema sequer semelhante ao que decorre da censura. E isso, por uma série de razões: (i) nestes casos é assegurada a liberdade de expressão, na medida em que não há censura prévia; (ii) a liberdade de expressão não é nem poderia ser um direito absoluto; (iii) a Constituição protege outros valores, como a honra, a imagem, a vida privada e a intimidade (art. $5^{\circ}, \mathrm{X}$ ); (iv) cabe ao Poder Judiciário a função justamente de dirimir uma lide, dizendo o direito num caso concreto; (v) a própria Constituição, após estabelecer que "é livre a manifestação do pensamento", assegurou, como contrapartida, não apenas o "direito de resposta, proporcional ao agravo", como a possibilidade de indenização por dano material, moral ou à imagem ${ }^{38}$.

Não obstante, em tempos de redes sociais tão presentes, onde é possível que o indivíduo se esconda por trás de um perfil e aborde tudo que bem entender, olvidando-se - propositalmente ou não - de preceitos fundamentais de vida em sociedade, essa liberdade muitas vezes é mal utilizada.

$\mathrm{O}$ apelo pelas redes sociais aumenta a cada ano no Brasil. Uma pesquisa do Instituto Datafolha, datada de 18 de junho de 2013, constatou que naquele momento essas têm mais prestígio e influência que políticos e instituições ${ }^{39}$.

Isso tudo faz parte da nova realidade vivida, tão criticada por Bauman. Para o autor, estaríamos vivendo a época da modernidade líquida. Essa seria a época da liquidez, da fluidez, de volatilidade e insegurança que retiram a segurança antes presente para dar espaço à regra agora vigente do consumo, do gozo e da artificialidade ${ }^{40}$.

\footnotetext{
${ }^{38}$ LEITE, Fábio Carvalho. Liberdade de Expressão e Direito à Honra: Novas Diretrizes para um Velho Problema. In: CLÈVE, Clèmerson Merlin; FREIRE, Alexandre (Org.). Direitos fundamentais e Jurisdição Constitucional: Análise, Crítica e Contribuições. $1^{\mathrm{a}}$ ed. São Paulo: Revista dos Tribunais, 2014. p. 395-408.

39 DATAFOLHA. Disponível em:

<http://datafolha.folha.uol.com.br/opiniaopublica/2013/06/1297630-rede-social-e-imprensa-temmaior-prestigio-e-poder-na-sociedade-brasileira-dizem-paulistanos.shtml/>. Acesso em: 10.12.2016.

${ }^{40}$ BAUMAN, Zygmunt. Modernidade Líquida. DENTZIEN, Plínio (Trad.). Rio de Janeiro: Zahar, 2003. $258 \mathrm{p}$.
} 
Não bastasse a população ainda estar em fase de adaptação a essa nova etapa da evolução, a classe jornalística também se vê afetada. Isso ocorre não apenas ao exercerem sua atividade tendo em vista que a produção de jornais impressos diminuiu drasticamente. O conteúdo que se vincula também é atingido.

A necessidade de se constatar tudo assim que acontece e ser o primeiro a informar prejudica toda sociedade, que se vê a mercê de informações muitas vezes inverídicas ou incompletas, apenas em razão da ganância e dos interesses de quem relatou o fato.

Essa nova era está afetando o direito à informação, que se encontra com um conteúdo mais ralo a cada dia, restrito à capa de um site de notícias ou aos 140 caracteres de uma rede social.

Portanto, por conta de tantas novidades trazidas nos últimos anos o direito de se expressar está mais amplo do que nunca, afetando áreas sensíveis da sociedade. As novas redes sociais são um amplo espaço para a democracia, não obstante seja necessária cautela em uma época com tantas novidades. Nunca foi tão fácil se expressar, contudo, na mesma moeda, nunca foi tão simples ofender o direito alheio.

\subsection{Do Direito à Informação}

Garantido na Constituição Federal de 1988, o direito à informação é de suma importância na vida de qualquer um, sendo certo que no Estado Democrático de Direito a população necessita tê-lo como uma garantia.

Não há dúvida de que o povo é o verdadeiro detentor do poder no país. Portanto, cabe ao mesmo fiscalizar as ações realizadas pelas esferas especificadas no artigo $2^{\circ}$ da Constituição. Contudo, para que esse controle seja de fato exercido, é imprescindível que se tenha conhecimento dos fatos, atos, opiniões e omissões dos representantes no exercício de suas funções públicas. 
Apenas dessa maneira é possível o verdadeiro exercício de cidadania e liberdade imaginadas pelo constituinte originário.

A importância do direito à informação na vida de qualquer indivíduo pode ser percebida ao constatarmos que se trata de um direito reconhecido e consagrado por diversos instrumentos internacionais de proteção aos direitos humanos: o artigo 19 da Declaração Universal dos Direitos Humanos, o artigo 19 do Pacto Internacional sobre Direitos Civis e Políticos, o artigo 13 da Convenção Interamericana sobre Direitos Humanos, o artigo $9^{\circ}$ da Carta Africana sobre os Direitos Humanos e dos Povos e o artigo 10 da Convenção Europeia sobre Direitos Humanos ${ }^{41}$.

Ao abordar essa questão, novamente é preciso retomar um pouco do que se passou no Brasil a partir da década de 1960, em que a liberdade foi restringida por conta do regime político imposto.

Nesse sentido, configurou-se a censura política à imprensa, que se distingue da censura de diversões públicas.

Isso ocorreu, pois no que toca à imprensa, o que regia era o destaque à divulgação de temas políticos em sentido estrito - e não apenas aspectos relacionados à proteção da moral e dos bons costumes. Em termos mais concretos, isso significa que a censura à imprensa se voltava, majoritariamente, para o controle sobre a veiculação de notícias, artigos de opinião e conteúdos jornalísticos por revistas, jornais e demais meios de comunicação, em uma tentativa de legitimação do regime instaurado.

Já a censura de diversões públicas baseava-se no conjunto de normas e na organização institucional que forneciam suporte a essa prática repressiva. É que, ao contrário da primeira, a censura à imprensa não era legalizada - justamente na tentativa de validar as atitudes tomadas - sendo sua existência sequer admitida, ao menos publicamente, pelos poderes constituídos, tanto que ela própria - a censura à imprensa - constituía um dos temas evitados pelo aparelho repressivo da ditadura civil militar.

\footnotetext{
${ }^{41}$ Agência de Notícias dos Direitos da Infância. Art. 19, 2009. p. 11.
} 
Tratava-se de uma forma de preservar a legitimidade do regime, evitando-se o surgimento de questionamentos às interdições dirigidas aos veículos de comunicação ${ }^{42}$.

Diante dessa dantesca conjuntura, o constituinte originário, ciente de que o direito à informação influencia no exercício do controle social e na manutenção de garantias fundamentais, forneceu o devido amparo constitucional ao seu exercício.

O direito do povo a ser informado está em todo o canto, desde a mera compra de um produto em um supermercado ${ }^{43}$ até na decisão de escolher os seus representantes. Essa significância ressalta-se em um país como o Brasil, que é pautado na ordem democrática institucional, pois o processo eleitoral é parte central na manutenção desse regime.

Nesse sentido, Eneida Desirre Salgado mostra o quão importante é essa estrutura para o Estado cujas premissas a Constituição fez nítida:

A autenticidade eleitoral também é um componente que faz parte do arcabouço que forma a estrutura do Estado de Direito, haja vista que na formação dos parlamentos e na indicação democrática do chefe do poder executivo, os procedimentos devem ser amparados em garantias de igualdade e de liberdade, sob pena de ilegitimidade do sistema representativo ${ }^{44}$.

A maneira de participar ativamente do processo democrático se relaciona com o conhecimento dos fatos, atos ou omissões praticados pelos sujeitos que se colocam à disposição para representar o povo. A construção de um juízo de valor pauta-se em um caminho diário em que informações chegam e pensamentos se formam, apenas assim a decisão tomada será consciente e responsável.

No entanto, deve-se ter em mente que a soberania popular vai além do mero voto prestado a cada biênio. Esse poder maior que a sociedade

\footnotetext{
43 BRASIL. Lei $n^{\circ}$. 8.078, de 11 de setembro de 1990. Art. 6º, III. Código de Defesa do Consumidor. Dispõe sobre a proteção do consumidor e dá outras providências. Disponível em: <http://www.planalto.gov.br/ccivil_03/Leis/L8078.htm>. Acesso em: 08.01.2017.

44 SALGADO, Eneida Desirre. Princípios Constitucionais Eleitorais. Belo Horizonte: Fórum, 2010. p. 33.
} 
possui permite que haja participação nas definições do Estado, uma vez que há o interesse de toda uma coletividade no acerto de tais tomadas de decisão. Um governo que não dialogar com os interesses da sociedade e não ouvir as vozes das ruas perde sua legitimidade a cada dia, com a consequência final de ser retirado pelo mesmo voto que lá o colocou.

A importância desse direito revela-se no fato de diversos governos não apenas no Brasil - não pouparem gastos de dinheiro público com publicidade. Essa é uma das espécies do gênero informação, sendo fundamental para que os representantes tentem passar suas mensagens sobre os principais fatos, com intuito de trazer a população para seu lado ${ }^{45}$.

Vejamos o que diz Noam Chomsky:

É necessário instigar a população para que apoie aventuras externas. Como aconteceu durante a Primeira Guerra Mundial, a população normalmente é pacifista. As pessoas não veem motivo para se envolver em aventuras externas, mortes e torturas. Portanto, você tem que instigá-las. E para instigá-las, é preciso amedrontá-las. (...) É preciso enfiar goela abaixo os programas domésticos com os quais a população não concorda, porque não há nenhuma razão para que ela seja favorável a programas domésticos que a prejudiquem. Isso também implica muita propaganda ${ }^{46}$.

Por isso é importante que haja uma imprensa que cubra os fatos e os atos praticados e forneça aos detentores do poder, qual seja, o povo, as informações pertinentes, para que cada sujeito, na sua individualidade, emita um juízo de valor próprio, pautando-se sempre pelo contraditório.

Positivado na norma magna, é indubitável que a informação é um direito fundamental, pois sua ausência impossibilita o ser humano de viver dignamente. $\mathrm{O}$ indivíduo que é ignorante em relação aos fatos que o circundam não será capaz de levantar a bandeira por seus direitos, pois mal terá a noção de quais são esses.

\footnotetext{
${ }^{45}$ FOLHA DE S. PAULO. Disponível em: <http://www1.folha.uol.com.br/colunas/laura-carvalho/2016/10/1820312-para-enfrentar-a-crisetemer-aumenta-gastos-com-publicidade.shtml>. Acesso em: 08.01.2017.

${ }^{46}$ CHOMSKY, Noam. Mídia, propaganda política e manipulação. SANTOS, Fernando (Trad.). São Paulo: WMF Martins Fontes, 2013. p. 34.
} 
Contudo, assim como todo direito, este pode sofrer violações por qualquer um, gerando até mesmo o dever de indenizar em certas circunstâncias.

José Afonso da Silva ilustra esse fenômeno dizendo que

Nesse sentido, a liberdade de informação compreende a procura, o acesso, o recebimento e a difusão de informações ou ideias, por qualquer meio, e sem dependência da censura, respondendo cada um pelos abusos que cometer ${ }^{47}$.

O direito à informação, essencial para o corpo social, deve ser enxergado pelas suas duas vertentes, quais sejam: o direito de informar e o de ser informado. Junto a isso, nasce uma responsabilidade daqueles que não prezam pela veracidade, imparcialidade e transparência das informações.

Dessa forma, reluz o quão significativa é a análise deste direito, tendo em vista que se vincula à consolidação da democracia, exigindo certos encargos daqueles que detém o poder-dever de informar.

\subsection{Da Liberdade de Imprensa}

Como dito acima, o direito à informação é fundamental, e tão importante quanto é ter uma fonte segura que forneça a informação, sob a égide de certos preceitos que devem guiar essa atividade, especialmente nos tempos de liquidez atuais.

A imprensa é um pilar para o exercício diário da democracia, pois é a partir da difusão da informação que se pode conter e reprimir os abusos de autoridades públicas.

É importante que conceitos de liberdade de expressão e de imprensa estejam claros, de maneira que não sejam confundidos. Enquanto o primeiro é uma maneira de qualquer um - pelas mais diversas formas

\footnotetext{
${ }^{47}$ SILVA, José Afonso da. Curso de Direito Constitucional Positivo. 16 ${ }^{\mathrm{a}}$ ed. rev. atual. São Paulo: Malheiros, 1998. p. 249.
} 
existentes - exibir seus pensamentos, o outro é especifico à atividade jornalística e seu livre exercício.

Paulo Cesar Salomão diferencia os conceitos de forma que não restem dúvidas sobre a liberdade de imprensa e a liberdade de expressão:

(...) em que estão a divulgação de fatos, dados, qualidades, objetivamente apurados de forma imparcial, com uma função social de contribuir para a elaboração do pensamento, se distingue da liberdade de expressão, em que está a livre expressão do pensamento por qualquer meio, com uma função social de difundir um pensamento ou posição já previamente elaborada ${ }^{48}$.

É notável que a mídia forma opiniões, e, nesse contexto, é capaz de alavancar tanto progressos quanto instabilidades em determinado lugar. Por essa razão, deve-se tratar com tanta cautela suas responsabilidades e obrigações.

Rui Barbosa, em 1920, vislumbrava já a relevância dos meios de comunicação para o País e as implicações de uma imprensa nociva:

\begin{abstract}
Entre as sociedades modernas, esse grande aparelho de elaboração e depuração reside na publicidade organizada, universal e perene: a imprensa. Eliminai-a da economia desses seres morais, eliminai-a, ou envenenai-a, e será como se obstruísseis as vias respiratórias a um vivente, o pusésseis no vazio, ou o condenásseis à inspiração de gases letais. Tais são os que uma imprensa corrupta ministra aos espíritos, que lhe respiram as exalações perniciosas. A imprensa é a vista da nação. Por ela é que a Nação acompanha o que lhe passa ao perto e ao longe, enxerga o que lhe malfazem, devassa o que lhe ocultam e tramam, colhe o que lhe sonegam, ou roubam, percebe onde lhe alvejam, ou nodoam, mede o que lhe cerceiam, ou destroem, vela pelo que lhe interessa, e se acautela do que a ameaça. (...) Um país de imprensa degenerada ou degenerescente é, portanto, um país cego e um país miasmado, um país de ideias falsas e sentimentos pervertidos, um país que, explorado na sua consciência, não poderá lutar com os vícios, que lhe exploram as instituições ${ }^{49}$.
\end{abstract}

Consoante a doutrina de José Afonso da Silva, é a partir da liberdade de informação jornalística que se encontra a liberdade de informar-se,

\footnotetext{
48 SALOMÃO, Paulo César. O Confronto entre o Direito à Intimidade e o Direito à Informação. Revista de Direito do Tribunal de Justiça do Estado do Rio de Janeiro. Rio de Janeiro. n. 66. 2006. p. 18.

49 BARBOSA, Rui. A Imprensa e o Dever da Verdade. São Paulo: Editora da Universidade de São Paulo, 1990. Disponível em: 〈http://www.casaruibarbosa.gov.br/interna.php?ID_S=105>. Acesso em: 09.02.2017.
} 
concretizando o efetivo direito coletivo à informação. Por conta disso, o ordenamento jurídico the confere um regime específico, que lhe garanta a atuação e lhe coíba os abusos ${ }^{50}$.

Portanto, existe um binômio em que de um lado se encontra a sociedade (que precisa de informações para entender e fiscalizar o andamento de tudo que a envolve) e de outro está quem traz essa informação ao povo - sendo fundamental haver atenção ao conteúdo exposto, tendo em vista a importância dessa atividade.

A verdade e o esclarecimento são necessários, e como tal, se tornam elementos essenciais para a existência de um regime democrático íntegro. Qualquer violação desses direitos pode levar à falsa percepção dos fatos, ferindo a possibilidade de formação e informação, o que acarretaria em um regime distante do Estado Democrático de Direito imaginado pelo constituinte originário.

Ainda pior ou tão ruim quanto uma falsa percepção dos fatos, a partir de vinculações tendenciosas e parciais, é a impossibilidade de se noticiar, ou seja, a censura.

O Ministro Barroso afirma que a Constituição proíbe, expressamente, a censura - isto é, a possibilidade de o Estado interferir no conteúdo da manifestação do pensamento - e a licença prévia, bem como protege o sigilo da fonte. ${ }^{51}$.

A participação das esferas estatais de poder na veiculação e no conteúdo das informações - sejam elas públicas ou privadas - consiste em atos de censura, que são expressamente vedados pela Constituição Federal no $\operatorname{artigo} 5^{\circ}$, IX, e artigo $220, \S 2^{\circ}$.

Para Rui Barbosa, a participação dos órgãos públicos em qualquer esfera da divulgação da informação fere os mais diversos direitos:

50 SILVA, José Afonso. Curso de Direito Constitucional Positivo. 20ª ed. São Paulo: Malheiros, 2001. p. 245.

${ }^{51}$ STF. MEDIDA CAUTELAR NA RECLAMAÇÃO 22.328. Relator Ministro: Luís Roberto Barroso. 20 de Novembro de 2015. 
Nessa linguagem se admite a hipocrisia de eventualidades, em que o governo possa entrar de bolsa aberta, pelas redações de jornais, como a libertinagem pelas casas de tolerância. Quando, evidentemente, em todo e qualquer caso, esses negócios abjetos são atos de lenocínio, dos quais ambas as partes saem contaminadas. Quando o que fazem os administradores públicos, tomando escritores de aluguel, para darem por suas as convicções, que lhes dita o suborno custeado pelos subornadores com dinheiro alheio, é mascararem de honradez o proxenetismo, e de verdade a mentira. Quando, em suma, com a torpeza desses costumes, os agentes do poder iludem a nação, de que são mandatários, dilapidam o patrimônio coletivo, de que são guardas, e lhe infestam a política de uma casta de parasitas (a mais maligna dos conhecidos no mundo moral) tão vis quanto virulentos e insaciáveis ${ }^{52}$.

Logo, é direito dos meios de comunicação se manifestar conforme sua consciência, sem haver a necessidade de qualquer interferência do Estado no conteúdo que se notícia.

Por óbvio, em uma manifestação na qual um direito tutelado seja violado, não haverá outra solução que uma sanção, sempre se pautando nos termos que a lei esclarecer, valendo-se tanto para a atividade jornalística quanto para qualquer manifestação. Contudo, essa resposta ao ato em nada se coaduna com a censura, mas apenas a um reflexo nos termos legais.

A única maneira de haver uma imprensa atuante e que cumpre seu papel é a partir da liberdade a ela concedida. Mas isso também impõe que ela não tenha poderes ilimitados.

A mídia é fundamental para a evolução da sociedade, vez que em um local em que é controlada os direitos humanos não prevalecerão frente aos interesses espúrios, sem que disso se tenha a exposição adequada para que o povo reaja.

Por isto, a responsabilidade que os órgãos da imprensa devem ter jamais pode ser confundida com uma forma de controle sobre sua atividade. A liberdade de expressão deve ser o carro-chefe dessa atividade, bem como de todo o corpo social, de forma que tudo possa ser comunicado sem qualquer modalidade de censura prévia.

\footnotetext{
${ }^{52}$ BARBOSA, A Imprensa e o Dever da Verdade, Acesso em: 05.03.2017.
} 


\subsubsection{Da Regulamentação}

Durante o período da ditadura civil-militar imposta ao Brasil em 1964, foi publicada a Lei $\mathrm{n}^{\circ} 5.250$, de 09 de fevereiro de 1967, que regulava os meios de comunicação.

Diante da ausência de regulamentação, essa ordem tinha o fulcro de controlar os jornalistas e suas atividades, por meio de sanções ao que fosse considerado ilegal. Como pretendido pelo governo à época, o exercício dessa profissão foi limitado por receio em relação às sanções que poderiam ser aplicadas aos que noticiariam as arbitrariedades existentes.

A partir dessa lei, o governo passou a controlar os meios de comunicação, sendo certo que qualquer um poderia ser submetido às penalidades abstratamente previstas. Para completar o dantesco cenário existente, a jurisdição não consagrava a garantia do devido processo legal, com a devida produção de provas. Dessa forma, os que eram os acusados de abusos tinham pouquíssimas chances se de defender, apesar de muitas vezes apenas terem cumprido seu papel de jornalistas.

Quando a imprensa é manipulada é capaz de trazer benefícios para aqueles que a dominam. Nesse contexto os militares apoiaram-se para disseminar a sua ideologia através de jornais impressos, revistas, rádio e televisão.

Em sede de Arguição de Descumprimento de Preceito Fundamental (ADPF 130$)^{53}$ o Supremo Tribunal Federal declarou inconstitucional a lei supracitada. $\mathrm{O}$ argumento principal foi que tal instituto possuía o condão de reprimir o trabalho da imprensa.

A desproporcionalidade entre as condutas e as sanções estava clara. Para exemplificar isso o artigo 17 da Lei é ideal ${ }^{54}$. O que seria ferir a moral

\footnotetext{
${ }^{53}$ STF. ADPF 130. Relator Ministro Carlos Ayres Britto. Brasília, 30 de abril de 2009.

${ }^{54}$ BRASIL. Lei no 5.250, DE 9 DE FEVEREIRO DE 1967. Regula a liberdade de manifestação do pensamento e de informação. Disponível em: <http://www.planalto.gov.br/ccivil_03/decretolei/1937-1946/Del1608.htm>. Acesso em: 20.03.2017.

Art. 17. Ofender a moral pública e os bons costumes:
} 
e os bons costumes? O que seria caracterizado como bons costumes? Conceitos tão amplos dão margem à discricionariedade de forma que a atividade da imprensa seria mitigada pelo medo

Segundo a Ministra do STF Carmen Lúcia Antunes Rocha em seu voto na citada ADPF, o fundamento e intuito da Lei de Imprensa seria o de "garrotear" a liberdade de expressão $0^{55}$, sendo certo que isso de forma alguma poderia se perpetuar.

A imprensa deve ser livre para exercer seu papel na sociedade da forma que entender melhor, partindo-se do pressuposto de que a liberdade aqui tratada é um direito inerente à sua atividade. Contudo, há regras a serem seguidas por quem dissemina a informação.

Inicialmente é preciso atentar que quem, por profissão ou ofício, incumbe-se de veicular informações, tem como dever garantir sua independência, não devendo por qualquer interesse proteger um fato, uma pessoa ou uma situação.

O jornalista pode defender uma posição parcial, contanto que isso seja expresso. O contrário, ou seja, um posicionamento que se diz imparcial, mas efetivamente é tendencioso, fere essa independência, e levará o cidadão a ter uma falsa percepção dos fatos, sendo esse ludibriado.

A consequência disso é a ofensa ao direito de se formular uma opinião sobre os fatos como eles realmente aconteceram, pois nesse caso a informação não é meramente um fato, mas também uma opinião transvestida de informação.

Pena: Detenção, de 3 (três) meses a 1 (um) ano, e multa de 1 (um) a 20 (vinte) salários-mínimos da região.

Parágrafo único. Divulgar, por qualquer meio e de forma a atingir seus objetivos, anúncio, aviso ou resultado de loteria não autorizada, bem como de jôgo proibido, salvo quando a divulgação tiver por objetivo inequívoco comprovar ou criticar a falta de repressão por parte das autoridades responsáveis:

Pena: Detenção de 1 (um) a 3 (três) meses, ou multa de 1 (um) a 5 (cinco) salários-mínimos da região.

${ }^{55}$ STF. Disponível em:

<http://www.stf.jus.br/portal/cms/vernoticiadetalhe.asp?idconteudo=107402〉. Acesso em: 20.03.2017. 
O Código Internacional dos Jornalistas ${ }^{56}$ é composto de princípios que organizam a atividade ao redor do mundo. Foi formulado no ano de 1983, após alguns encontros entre importantes Confederações e Uniões de Jornalistas dos vários continentes.

Entre os princípios a serem seguidos por jornalistas de todos os países, destaca-se a garantia de que não apenas no Brasil a informação é protegida como direito fundamental ${ }^{57}$.

Justifica-se a relevância do estudo deste direito, sobretudo a partir do papel que ocupa na consolidação da democracia ao redor do mundo, sendo certo que para tanto, exige-se responsabilidade de quem transmite a informação aos diversos setores da sociedade.

Em uma cobertura imparcial os fatos devem falar por si, não cabendo um juízo de valor implícito, inserido na cobertura/divulgação, pois isso fere a independência e o direito à informação. O Código de Ética dos Jornalistas Brasileiros (FENAJ) proíbe essa conduta em seu artigo 10, alínea $b^{58}$.

56 FENAJ. Disponível em: <http://fenaj.org.br/legislacao-profissional/juridica/>. Acesso em: 20.03.2017.

${ }^{57}$ Código Internacional dos Jornalistas:

Principio I - Direito das Pessoas à informação verdadeira

Pessoas e indivíduos têm o direito em receber uma figura objetiva da realidade a partir de uma informação precisa e compreensiva, bem como de se expressar livremente por meio de várias mídias da cultura e comunicação.

Principio III - A responsabilidade Social do Jornalista

Informação no jornalismo é entendida como bem social, não como comodidade, o que significa que o jornalista divide a responsabilidade pela informação transmitida e essa responsabilidade é não só em relação àqueles quer controlam a mídia, mas ultimamente ao público em larga escala, incluindo os diversos interesses sociais. A responsabilidade social do jornalista requer que ele ou ela hajam em todas as circunstancias em conformidade com sua consciência ética.

Principio VII - Respeito pelo interesse do publico

O padrão profissional do jornalismo prescreve respeito pela comunidade nacional, pelas instituições púbicas e morais

Principio VIII - Respeito pelos valores Universais e pela diversidade de culturas

O verdadeiro jornalista está junto dos valores universais da humanidade, sobretudo a paz, a democracia, os direitos humanos, o progresso social e liberdade nacional, enquanto respeita o caráter distintivo, o valor e a dignidade de cada cultura, bem como pelo direito de cada pessoa livremente escolher e desenvolver seu sistema político, social, econômico e cultural. Assim o jornalista participa ativamente na transformação social em direção ao melhoramento democrático da sociedade e contribui a partir do dialogo a um clima de confiança nas relações internacionais conducentes à paz e à justiça em toda parte, bem como ao desarmamento e ao desenvolvimento nacional. É da ética da profissão que o jornalista deve estar ciente das disposições relevantes contidas nas convenções, declarações e resoluções internacionais. (Traduzido em 17/04/2017).

58 Art. 10. O jornalista não pode:

$[\ldots]$ 
O dever do jornalista de informar algo nos termos dos acontecimentos está diretamente ligado com o já abordado direito à informação. Isso denota a responsabilidade que este profissional possui para com toda a sociedade, pois para a manutenção da estrutura de poder existente, o povo deve manter-se informado do ocorrido de maneira que seja possível exercer seu poder de fiscalização.

Diante disso, o engajo de se manter imparcial e de apenas divulgar o que for correspondente com a verdade se torna imprescindível. E ainda que haja um posicionamento, que este seja explicitamente um juízo de opinião, não se confundindo com uma informação.

O Código de Ética citado, em seu artigo $4^{\circ}$, elucida a importância desse dever com a verdade, ressaltando que o jornalista deve buscar apurar sobre o fato antes de divulgá-lo ${ }^{59}$.

Aquele que violar as regras impostas estará sujeito a sanções, de forma que o caso pode ser enviado ao Ministério Público para outras providências, conforme determinam os artigos 17 e 18 do referido Código de Ética ${ }^{60}$, mas isso não se confunde com as arbitrariedades do passado.

Contudo, em tempos nos quais a notícia é divulgada em apenas 140 caracteres, o marketing vem se tornando muito mais importante do que a qualidade da informação prestada. O que se enxerga é uma certa necessidade de divulgar o fato antes de um concorrente, não se pesando o custo de uma informação incompleta ou até mesmo errônea.

\footnotetext{
b) submeter-se a diretrizes contrárias à divulgação correta da informação.

${ }^{59} \mathrm{Art.} 4^{\circ} \mathrm{O}$ compromisso fundamental do jornalista é com a verdade no relato dos fatos, razão pela qual ele deve pautar seu trabalho pela precisa apuração e pela sua correta divulgação.

${ }_{60}$ Art. 17. Os jornalistas que descumprirem o presente Código de Ética estão sujeitos às penalidades de observação, advertência, suspensão e exclusão do quadro social do sindicato e à publicação da decisão da comissão de ética em veículo de ampla circulação.

Parágrafo único - Os não-filiados aos sindicatos de jornalistas estão sujeitos às penalidades de observação, advertência, impedimento temporário e impedimento definitivo de ingresso no quadro social do sindicato e à publicação da decisão da comissão de ética em veículo de ampla circulação. Art. 18. O exercício da representação de modo abusivo, temerário, de má-fé, com notória intenção de prejudicar o representado, sujeita o autor à advertência pública e às punições previstas neste Código, sem prejuízo da remessa do caso ao Ministério Público.
} 
É relevante o que diz Carvalho sobre o tema, utilizando uma comparação perfeita quanto ao que enfrenta o jornalista em seu trabalho diário:

Os agentes informadores devem prestar lealdade à verdade e devem se dispuser a persegui-la com a mesma imparcialidade com que o magistrado persegue a reconstituição do fato. Não se está dizendo que o magistrado e o agente informador tenham que ser neutros em relação ao processo social ou alienados politicamente. Não! O que se está postulando é que, em razão de o magistrado, bem como o profissional da informação trabalharem com o fato, para sobre ele aplicarem a experiência de suas funções, a perseguição e a divulgação do fato deva ser precedida com isenção total e completa. O magistrado busca o fato pretérito e sobre ele aplica o conhecimento que tem. O informador busca o fato que está acontecendo, o que acabou de acontecer, o fato presente, para informar a sociedade. Tanto ele como a sociedade precisam do fato objetivamente apurado para estabelecer suas conclusões. A narrativa do fato pelo magistrado (no relatório da sentença) e pelo informador (na reportagem) não pode estar comprometida pela sua avaliação sobre o mesmo fato. Somente após a apuração do fato, como ele realmente ocorreu, pode o juiz concluir (na fundamentação da sentença) e o informador criticar (no editorial do jornal), mas tudo com inteira transparência. O informador que distorce o fato é tão parcial quanto o juiz. A missão pública que ambos desempenham não lhes permite tanta liberdade ${ }^{61}$.

Não é permitido aos veículos de comunicação exibir o que bem entenderem, tendo em vista que possuem uma responsabilidade com a sociedade, e ainda assim, isso não se confunde jamais com qualquer modalidade de censura. $\mathrm{O}$ que está em jogo é um direito fundamental que se relaciona com os rumos da coletividade e com toda a estrutura idealizada pelo constituinte.

${ }^{61}$ CARVALHO, Luiz Gustavo Grandinetti Castanho de. Direito de Informação e Liberdade de Expressão. Rio de Janeiro: Renovar, 1999. p. 96. 


\section{CAPÍTULO 3 - DA APLICAÇÃO CONCRETA}

Até o momento foram destacados os elementos da organização do estado brasileiro bem como a função da imprensa e do direito à informação. Agora, a partir da análise de três casos concretos, será possível ver como esses dois tópicos estão intrinsecamente ligados.

Contudo, apesar de em certos momentos ser necessário adentrar nas questões relevantes de cada caso, o escopo principal de maneira alguma é discutir os mesmos, pois são todos bastante controversos, merecendo destaque em um trabalho aprofundado sobre os mesmos.

O objetivo ao analisá-los é ver sobre qual perspectiva a imprensa os abordou, sobretudo para entendermos em cada um se a mesma cumpriu com o papel que dela se espera.

Os três casos tratados serão:

- Impeachment do Ex-Presidente Fernando Collor de Melo

- Impeachment da Ex-Presidenta Dilma Roussefff

- Cassação do Ex-Presidente da Câmara dos Deputados Eduardo Cunha

\subsection{Impeachment Do Ex-Presidente Fernando Collor De Melo}

Fernando Collor de Mello - atualmente Senador pelo estado de Alagoas - foi o primeiro presidente eleito pelo voto direto, em 1989, após 29 anos sob o regime da ditadura-civil militar. Após 3 anos de mandato o então Presidente foi condenado à perda do cargo cominada com a perda de seus direitos políticos.

Durante os quase mil dias de governo, o ex-presidente passou por diversas turbulências, a partir de pressões de todos os setores da sociedade, que culminaram com o fim anunciado. 
Inicialmente, é necessário situar o período que antecipou a eleição do ex-Presidente Collor, mais precisamente o período eleitoral que o levou à presidência ao enfrentar Luís Inácio Lula da Silva.

A disputa pela chance de governar o país era intensa entre os dois candidatos, de forma que pesquisas indicavam um empate técnico até o dia do debate mediado pela Rede Globo de Televisão ${ }^{62}$. No entanto, assumindo o lado de Collor, a mediadora do debate não exerceu apenas essa função, pois o próprio diretor da emissora, José Bonifácio de Oliveira Sobrinho conhecido como Boni - admitiu em 2011 que "foi uma maneira de melhorar a postura do Collor junto ao espectador para tentar colocá-lo em pé de igualdade com a popularidade do Lula"63.

Desta forma, fica nítido que o que seria um espaço de exposição de ideias entre os candidatos, que estariam em igualdade, foi manipulado por uma atitude parcial por parte da emissora em uma tentativa de ajudar a parte que, no seu entendimento, seria mais adequada ao país.

Eis a explicação do historiador Gilberto Maringoni:

Os principais jornais ficaram entusiasmados, pois o projeto do Collor coroava uma disputa de rumos no fim dos anos 80. Ele era visto como a saída para que o mercado fosse o polo dinâmico e comandasse a economia. O Collor tinha o projeto econômico que a elite queria ${ }^{64}$.

Embora seja difícil mensurar o quanto a atitude durante o debate foi impactante ou não nos votos de 17 de dezembro de 1989, essa atitude não condiz com a boa-fé jornalística e seu dever de informar.

Passadas as eleições, Collor assumiu em momento de grave crise econômica em um país cuja democracia ainda engatinhava. Havia esperança nesse momento, sendo certo que a mídia colaborava nesse

\footnotetext{
${ }^{62}$ GLOBO. Disponível em:

$<$ http://memoriaglobo.globo.com/programas/jornalismo/coberturas/eleicoes-presidenciais-1989/osegundo-turno.htm>. Acesso em: 01.04.2017.

${ }^{63}$ Disponível em: 〈https://www.youtube.com/watch?v=VrpurEkmJkU>. Acesso em: 01.04.2017.

${ }^{64}$ GAZETA DO POVO. Disponível em:

$<$ http://www.gazetadopovo.com.br/vida-publica/especiais/impeachment-20-anos/um-presidentefeito-e-desfeito-pela-imprensa-2zd0gilpep3bxuw32brc3fd5a>. Acesso em: 01.04.2017.
} 
sentido. Prova maior é a falta de elucidação sobre as duras medidas voltadas para a economia, que poderiam ter sido muito mais questionadas e levadas a debate de toda a população.

No entanto, a situação virou contra o Presidente após a bombástica entrevista de seu irmão, Pedro Collor, à revista Veja em maio de $1992^{65}$.

De acordo com o irmão mais novo do Presidente, o ex-tesoureiro da campanha presidencial (Paulo César Farias - conhecido como "PC Farias") pressionava as empresas, extorquindo-as, utilizando-se do nome de Collor para tal.

Pedro Collor acusou Fernando Collor de, com Paulo César, utilizar frutos de negócios ilegais para campanhas e despesas de cunho pessoal em trechos como o que segue:

(...)VEJA - O senhor acha mesmo que o PC é um testa-de-ferro do Presidente nos negócios?

Pedro Collor - Eu não acho, eu afirmo categoricamente que sim. O Paulo César é a pessoa que faz os negócios de comum acordo com o Fernando. Não sei exatamente a finalidade dos negócios, mas deve ser para sustentar campanhas ou manter o status quo(... $)^{66}$.

No dia seguinte ao da publicação da revista, o foco da mídia, bem como de toda a sociedade eram as declarações de Pedro Collor. Nesse ponto, deve-se destacar que a imprensa cumpria o papel que dela se espera. Ou seja, em primeiro lugar, buscou a fonte que relataria um grave escândalo na política brasileira, e posteriormente, investigou a veracidade ou não das informações que lhe foram passadas. Essa cobertura não era partidária, e tinha como único objetivo a busca pela verdade dos fatos, exercendo o veículo de comunicação sua função social.

\footnotetext{
${ }^{65}$ VEJA. Disponível em: <http://veja.abril.com.br/blog/reinaldo/a-entrevista-que-pedro-concedeua-veja-ha-20-anos-e-que-esta-na-raiz-do-odio-que-fernando-collor-tem-da-revista/>. Acesso em: 20.04.2017.

${ }^{66}$ Ibid., Acesso em: 20.04.2017.
} 
Por conta das supostas irregularidades do ex-Presidente, em 25 de maio daquele ano, a pedido do Partido dos Trabalhadores (PT), foi instaurada uma Comissão Parlamentar de Inquérito (CPI) para investigar o caso em questão.

Crescia a insatisfação popular, a qual teve origem na reportagem jornalística da revista Veja, que pretendia informar a todos as atitudes espúrias observadas em Brasília.

Em 28 de Junho, mais uma vez a mídia buscou informações e conseguiu contribuir na busca pela veracidade dos fatos. A revista Isto É entrevistou Eriberto França, motorista de Collor à época, o qual revelou que Paulo Cesar Farias, além do escândalo antes exposto, ainda pagava as contas da Casa da Dinda (residência do Presidente e da sua família), por meio da empresa Brasil-Jet, de sua propriedade ${ }^{67}$.

A Comissão Parlamentar de Inquérito comprovou essa afirmação de Eriberto e ainda revelou que a secretária particular do Presidente recebia depósitos de Paulo Cesar por vias irregulares.

Para completar o cenário, foi revelado pelo jornalista Jorge Bastos Moreno a compra, também a partir de Paulo Cesar pelas mesmas fontes irregulares de um Fiat Elba, que se tornou o símbolo daquele esquema de corrupção, lembrado até os dias de hoje $\mathrm{e}^{68}$.

Essa informação aumentou a pressão já altíssima contra os desmandos agora de conhecimento público, resultando em movimentos de repulsa de todos os cantos da sociedade, impulsionados sobretudo pela mídia.

\footnotetext{
${ }^{67}$ ISTOE. Disponível em: <http://istoe.com.br/161904_DEPOIMENTO+DE+MOTORISTA+LEVA+AO+IMPEACHMENT +DO+PRESIDENTE>. Acesso em: 20.04.2017.

${ }^{68}$ GLOBO. Disponível em:

<http://memoriaglobo.globo.com/programas/jornalismo/coberturas/impeachment-de-collor/orelatorio-final-da-cpi.htm>. Acesso em: 20.04.2017.
} 
O editorial publicado na Folha de São Paulo, em 29 de setembro de 1992, demonstra claramente que o clima que uma vez foi de paciência com o Presidente havia se transformado:

[...] A sociedade já proferiu o seu veredito, a altura do crime cometido contra a nação: Fernando Collor deve deixar a Presidência da República, por não ter observado o decoro e a dignidade inerentes à instituição. Espera-se agora dos 503 parlamentares [...] que cumpram com sua obrigação moral e política: autorizar o processo de impeachment de um presidente que envergonha o Brasil. [...] A reforma da sociedade e do Estado brasileiro, que Collor inquestionavelmente contribuiu para inscrever na agenda das prioridades do país, avançou timidamente, sob o peso colossal de práticas oligárquicas $[\ldots]^{69}$.

Na mesma linha seguiu Jornal do Brasil:

Finalmente - é preciso lembrar -, o presidente da República elegeu-se como caçador de marajás, empolgando o país com uma campanha de moralização dos costumes e prometendo regenerar a vida pública brasileira, marcada pela corrupção, pelo clientelismo e pela impunidade. Collor não honrou tal compromisso e comprometeu toda a sua plataforma de governo. Por essa razão o JORNAL DOBRASIL retirou seu apoio ao presidente, nesta hora de definição inapelável. [...] A defesa não veio. [...] Nada do que Collor disse até agora ajuda a identificar os fantasmas que andaram engordando a sua conta bancária, vestindo a primeira-dama e refazendo seus jardins miríficos. Em face de tudo isso, e em nome dos mais altos interesses da nação, o JORNAL DO BRASIL espera que os congressistas sejam fiéis ao sentimento geral do povo brasileiro e votem pela admissibilidade do processo de impeachment do presidente da República $[\ldots]^{70}$.

O envolvimento da imprensa chegou às ruas com o movimento dos “caras pintadas", liderado por pessoas que se vestiam de preto e pintavam o rosto de verde e amarelo para exigir a saída do Presidente e a prisão de Paulo Cesar Farias.

Na mesma época, a Ordem dos Advogados do Brasil (OAB), a Conferência Nacional dos Bispos do Brasil (CNBB), a Central Única dos Trabalhadores (CUT) e partidos de oposição realizaram uma manifestação, chamada de "Vigília pela Ética na Política", para pressionar os

69 FOLHAPRESS. Folha de São Paulo. "Impeachment". 29/9/1992:1. Disponível em: <http://www.snh2015.anpuh.org/resources/anais/39/1443808918_ARQUIVO_Vinicius_Franca.pd f>. Acesso em: 20.04.2017.

${ }^{70}$ Ibid., Acesso em: 20.04.2017. 
congressistas no sentido de checar devidamente os fatos e punir os envolvidos ${ }^{71}$.

É importante lembrar que Collor chegou ao cargo mais visado da política brasileira nos braços da maior difusora de informações do país, restando por óbvio um questionamento: o que teria ocasionado essa mudança em relação ao tratamento da mídia com o Presidente?

Essa alteração de comportamento já foi muito debatida. Gilberto Maringoni mostra dois erros políticos que custaram o suporte a Fernando Collor:

i) não se importou em manter a maioria no Congresso

ii) entrou em confronto com o empresariado

Dessa forma não havia base de apoio forte suficiente para resistir à pressão criada. A imprensa, inicialmente ao seu lado, passou a buscar maiores informações sobre os bastidores políticos, chegando a todos aqueles indícios de corrupção.

O processo na Câmara continuou a tramitar e foi aprovado o parecer que pedia o afastamento e dava início ao processo de impeachment, por 441 votos favoráveis, de acordo com os ditames constitucionais ${ }^{72}$.

O Presidente foi afastado por 180 dias e caberia ao Senado julgá-lo ${ }^{73}$. Em 29 de dezembro ocorreu a última fase do processo de Collor por crime de responsabilidade; no entanto, antes do final, diante da tendência dos senadores de afastá-lo definitivamente e da iminente perda do cargo combinado com a suspensão de seus direitos políticos, Fernando Collor decidiu renunciar.

\footnotetext{
${ }^{71}$ ESTADÃO. Disponível em:

<http://acervo.estadao.com.br/noticias/topicos,impeachment-de-collor,887,0.htm>. Acesso em: 20.04.2017.

72 Constituição da República Federativa do Brasil. Art. 86.

BRASIL. Constituição (1988). Acesso em: 20.04.2017.

${ }^{73}$ Ibid., Art. 86, §1, II.
} 
Tendo em vista que o processo já estava aberto, apesar da renúncia, o ex-Presidente teve seus direitos políticos suspensos por oito anos, até 2000. Esse fato gerou a insatisfação de alguns juristas, que acreditavam que com a renúncia o processo perderia seu objeto. Contudo, esse não foi o entendimento majoritário, que optou por impor uma ação que não apenas a perda do mandato.

Dessa forma, é incontroversa a participação da imprensa nessa parte da história brasileira, demonstrando que sua influência vai além da mera divulgação de fatos, mas pode ocorrer também investigando e trazendo a verdade à tona.

Sua atuação ativa no caso foi fundamental para esclarecer os fatos que se passavam nos corredores de Brasília, aos quais o povo jamais teria acesso sem os veículos de comunicação. A busca pela veracidade e sua divulgação correspondem a um dever da imprensa e essa deve obedecer a esse comando para promover a melhora da situação social no país.

Nessa situação a corrupção foi comprovada e coube à imprensa descobrir e divulgá-la de todas as formas possíveis, cabendo ao povo, em geral, exercer pressão sobre os seus representantes para que agissem e afastassem um Presidente comprovadamente corrupto.

A organização do Estado deve ser nos ditames previstos pelo constituinte originário, sendo papel de toda a coletividade - inclusive da imprensa - fiscalizar para que isso esteja sendo cumprido, pois caso não seja dessa forma, quem estiver agindo contrariamente deve ser afastado.

\subsection{Impeachment Da Ex-Presidenta Dilma Rousseff}

Enquanto no primeiro caso tratamos de uma atuação positiva da imprensa, que buscou informações, tratou de ouvir as partes envolvidas, tendo a busca pela informação de qualidade em primeiro lugar, nesse caso veremos um outro viés, qual seja, da omissão da mesma. 
Inicialmente, devemos nos ater às circunstâncias que rodeavam o gabinete da Chefe do Executivo Federal. Dilma Rousseff foi reconduzida ao cargo em 2014 após vencer Aécio Neves no segundo turno das eleições.

A diferença de votos entre um e outro foi pequena, o que demonstra sem dúvida um país dividido, contudo, isso faz parte do jogo democrático. Não é razoável que a diferença entre votos deslegitime quem se elege, pois define a Constituição que será eleito quem tiver a maioria absoluta de votos, não computados os votos brancos e nulos, não havendo um terceiro turno ${ }^{74}$.

No entanto, uma parcela da população não aceitou bem o resultado por essa diferença, intensificando a oposição ao governo - o que também pertence ao jogo democrático.

O descontentamento em relação ao governo estava relacionado à manutenção do Partido dos Trabalhadores (PT) no poder pelo que seriam 4 ciclos presidenciais, caso o mandato da Presidenta fosse cumprido. A imagem do partido estava arranhada, muito em função do processo judicial de maior repercussão nos últimos tempos, que prendeu membros importantes da sigla, como por exemplo José Dirceu.

Em linhas gerais, pode-se dizer que a partir de março de 2014, perante a Justiça Federal em Curitiba, foram investigadas e processadas quatro organizações criminosas lideradas por doleiros, que são operadores do mercado paralelo de câmbio. Por conta disso, o Ministério Público Federal denunciou diversas pessoas em um esquema de corrupção envolvendo empresas estatais. Nesse esquema, as maiores empreiteiras do país formavam um cartel e pagavam propina à agentes públicos de diversos setores em contratos bilionários superfaturados. Essa compra era distribuída através de operadores financeiros do esquema, incluindo doleiros investigados na primeira etapa.

\footnotetext{
${ }^{74}$ Constituição da República Federativa do Brasil. Art. 77, §2. BRASIL. Constituição (1988). Acesso em: 01.05.2017.
} 
Para piorar o cenário o governo ainda tentou estimular uma força parlamentar alternativa para diminuir a dependência do PMDB, aliado desde a composição da chapa concorrente, e vitoriosa, mas historicamente traiçoeiro.

O plano, que consistia em inflar partidos como Partido Social Democrático (PSD) e Partido Republicano da Ordem Social (PROS), foi mal executado, e elevou Eduardo Cunha à condição de opositor declarado um erro de cálculo que custaria caro ao Planalto meses à frente ${ }^{75}$.

Com essa estratégia, cada partido receberia duas pastas, existindo negociação até com o pequeno Partido Trabalhista Nacional (PTN) para uma participação importante junto ao Ministério do Turismo. Até então o PMDB possuía mais cargos ligados ao governo em relação aos demais, sendo certo que a partir desse divórcio, muitos foram exonerados ${ }^{76}$.

Com o Congresso Nacional votando contra as medidas econômicas que o Executivo tentava emplacar, a crise econômica piorava, com o desemprego e a inflação crescentes, o que sempre é um dos fatores principais para gerar uma crise de governabilidade.

Nesse contexto, a população em boa parte se voltava contra o governo, com manifestações por todo Brasil, pedindo melhoras, e, sobretudo, o fim da corrupção.

A imprensa passou a incentivar a insatisfação, como se houvesse unanimidade no Brasil, tratando os opositores como defensores do melhor para o país. Importante lembrar que esses mesmos veículos de comunicação em outros momentos usavam termos pejorativos para designar quem ia às ruas exigindo direitos, exercendo a liberdade de expressão.

\footnotetext{
${ }^{75}$ FOLHA DE S. PAULO. Disponível em: <http://www1.folha.uol.com.br/especial/2015/brasilem-crise/o-impeachment-de-dilma/\#como-tudo-comecou>. Acesso em: 01.05.2017.

${ }^{76}$ FOLHA DE S. PAULO. Disponível em: <http://painel.blogfolha.uol.com.br/2016/03/31/planopara-salvar-dilma-Roussefff-passa-por-inflar-ministerios-de-pp-pr-e-psd-ate-ptn-recebeu-oferta/> . Acesso em: 01.05.2017.
} 
Até então, a mídia vinha cumprindo seu papel, qual seja, noticiar os fatos ocorridos e debatê-los. A crise econômica era uma grande verdade, a falta de diálogo também e a operação lava-jato - que era um sinal de luta para os opositores. Não obstante, ainda que com todo esse contexto, o que poderia se cobrar da Presidenta era uma melhora em sua atuação, mas não a acusar de um crime com uma fundamentação duvidosa.

A pressão cresceu tanto que o impeachment começou a ser abordado pela sociedade, tratado como uma possibilidade de afastar-se uma Presidenta que não conseguiria dar rumos desejados pela oposição. Essa encontrou a base de tal pedido que seria a prática de uma manobra contábil - as "pedaladas fiscais".

Resumidamente deve-se esclarecer que governo deve repassar verba para bancos, públicos e privados, que auxiliam programas e benefícios sociais, como o Bolsa Família, o Minha Casa Minha Vida, o segurodesemprego e as aposentadorias públicas. Esse repasse é de responsabilidade do Tesouro Nacional.

No entanto, nos últimos tempos, o governo atrasou - segundo a acusação deliberadamente - diversos desses repasses. Segundo esses, os atrasos serviriam para bater as metas fiscais (ou seja, para não permitir que as contas públicas ficassem negativas). Dessa forma, a quantia não repassada seria utilizada para mascarar a situação financeira.

Esse atraso de repasses com o objetivo de maquiar as contas públicas seriam as pedaladas fiscais. Contudo, atrasos semelhantes foram registrados em governos anteriores, mas envolveram somas de recursos muito menores.

Segundo o pedido de impedimento, esse uso de verba dos bancos para cobrir o atraso dos repasses do governo seria um tipo de financiamento da União. Contudo, o artigo 36 da Lei de Responsabilidade Fiscal proíbe empréstimos entre a União e instituições financeiras que ela controla, caracterizando um crime de responsabilidade fiscal, o que seria entendido como um crime de responsabilidade. 
A defesa da Presidenta alegava que essa prática era comum em governos anteriores, como o de Fernando Henrique Cardoso e o de Luiz Inácio Lula da Silva, bem como que outros governos - estaduais - fariam o mesmo. Ademais, dizia que os repasses não podem ser vistos como empréstimos, mas como prestações de serviço para pagamento de benefícios sociais, de forma que não haveria incidência da Lei de Responsabilidade Fiscal.

O movimento em favor da saída da Chefe do Executivo cresceu e foi às ruas de forma que em pesquisa feita pelo Instituto Data Folha, em 19 de março de 2016, sobre como os deputados deveriam votar em relação ao impeachment da Presidenta Dilma Rousseff, 68\% achavam que deveriam votar a favor do afastamento ${ }^{77}$.

Dentro desse cenário de crise, Eduardo Cunha, então Presidente da Câmara dos Deputados, iniciou os trabalhos de tramitação do processo, e, em 23 de setembro de 2015, definiu o rito a ser seguido, e dentro da sua competência $^{78}$, deu início ao processo em 02 de dezembro de 2015.

Aumentando ainda mais a pressão, o então Vice-Presidente Michel Temer ofereceu à mídia e à população um prato cheio para que um movimento oposicionista crescesse.

Em carta endereçada à Presidenta da República, Michel Temer joga gasolina em um ambiente já conturbado, em trechos como este: "Finalmente, sei que a senhora não tem confiança em mim e no PMDB, hoje, e não terá amanhã. Lamento, mas esta é a minha convicção ${ }^{79}$ ",

\footnotetext{
${ }^{77}$ G1. Disponível em:

<http://g1.globo.com/politica/noticia/2016/03/68-apoiam-impeachment-de-dilma-diz-pesquisadatafolha.html >. Acesso em: 01.05.2017.

78 BRASIL. Câmara dos Deputados. Regimento Interno, estabelecido pela Resolução n. 17, de 1989. Art. 217. Disponível em: 〈http://www2.camara.gov.br/legislacao/regimentointerno.html〉. Acesso em: 01.05.2017.

${ }^{79}$ G1. Disponível em:

<http://g1.globo.com/politica/noticia/2015/12/leia-integra-da-carta-enviada-pelo-vice-micheltemer-dilma.html>. Acesso em: 01.05.2017.
} 
Esta carta aberta expôs o governo, que virou mais do que nunca alvo da mídia e da população, tendo em vista que se difundiu a visão de que se a Presidenta não conseguia dialogar com o seu Vice-Presidente, imagine o que seria com o restante da sociedade.

Na sequência, o pedido de impedimento da Presidenta foi aprovado pela Comissão Especial da Câmara e, posteriormente, pelo Plenário por 367 votos favoráveis e 137 contrários.

O processo foi para o Senado que também aprovou o pedido tanto em uma Comissão Especial quanto em plenário, contabilizando 55 votos favoráveis e 22 contrários à abertura do processo em 06 de maio de 2016, sendo, então, afastada de suas funções por 180 dias a Presidenta Dilma Rousseff.

Nesse sentido, cumpre ressaltar que essa foi apenas a primeira votação realizada na Casa dos Representantes dos Estados, pois se interpretou o artigo 86 da Constituição de maneira que primeiro haveria uma votação sobre a abertura do processo, tal qual ocorreu na Câmara, e, depois, os senadores analisariam o mérito, em sessão presidida pelo Presidente do Supremo Tribunal Federal.

Em 10 de agosto de 2016 o plenário do Senado decidiu, por 59 votos a 21, afastar a Presidenta Dilma Rousseff de suas funções, mantendo os direitos políticos da Presidenta, apesar da Constituição definir as duas sanções em conjunto, o que foi duramente criticado no Supremo Tribunal Federal pelo Ministro Gilmar Mendes:

\footnotetext{
Considero essa decisão constrangedora, é verdadeiramente vergonhosa. Um presidente do Supremo (então, Lewandowski) não deveria participar de manobras ou de conciliados. Portanto não é uma decisão dele. Cada um faz com sua biografia o que quiser, mas não deveria envolver o Supremo nesse tipo de prática. ${ }^{80}$
}

\footnotetext{
${ }^{80}$ FOLHA DE S. PAULO. Disponível em: $<$ http://politica.estadao.com.br/noticias/geral,votacao-fatiada-de-impeachment-e-no-minimobizarro-diz-gilmar-mendes, 10000073485
} 
Ao analisar a atuação da imprensa em todo o trâmite do processo, constata-se que a mesma noticiava os fatos, mas sem profundidade, e muito menos tentando elucidar as acusações, sobretudo para a população leiga no assunto.

Não se adentrou no mérito dos crimes supostamente cometidos, sendo certo que o debate foi muito superficial em relação ao que deveria ter sido. Essa atitude se caracteriza como uma falha jornalística, tendo em vista que a prática fiscal tida como base da acusação não era de fácil compreensão nem para técnicos, e muito menos para a população ignorante em relação ao tema ${ }^{81}$.

Para demonstrar como a questão era delicada, o próprio Ministério Público em sua manifestação informou que as "pedaladas" não eram crimes, de acordo com o parecer enviado à Justiça $\mathrm{O}$ procurador da República no Distrito Federal, Ivan Marx, pediu o arquivamento de investigação aberta para apurar possível infração penal de autoridades do governo da Presidenta afastada. Ele concluiu, no entanto, que as manobras visaram maquiar as contas públicas, principalmente no ano eleitoral de 2014, havendo improbidade administrativa - um delito civil ${ }^{82}$.

Dessa forma, a grande mídia não tentou esclarecer os fatos minuciosamente, limitando - se a apenas noticiá-los superficialmente. É preciso que se entenda que a partir do momento em que os veículos de comunicação optaram por não expor a realidade dos fatos, qual seja, a postura dos congressistas para tirar a Presidenta sem motivo concreto, essa está sendo parcial em sua atividade.

A população reagiu a tantas notícias negativas em relação ao governo desejando que medidas fossem tomadas diante da pressão, pois o

\footnotetext{
${ }^{81}$ FOLHA DE S. PAULO. Disponível em:

<http://www1.folha.uol.com.br/poder/2015/10/1698480-a-exemplo-de-dilma-estados-tambemfizeram-manobras-fiscais-em-2014.shtml>. Acesso em: 01.05.2017.

${ }^{82}$ ESTADÃO. Disponível em:

$<\mathrm{http}: / /$ politica.estadao.com.br/noticias/geral,para-mp-pedaladas-do-governo-dilma-nao-saocrime,10000062862>. Acesso em: 01.05.2017.
} 
mantra de combate à corrupção estava espalhado, e para parte do povo, combater o governo era uma maneira de fazê-lo.

Contudo, se a imprensa noticiava os fatos, faltou também informar que as formalidades em relação ao rito não são suficientes para motivar um impeachment, pois a letra constitucional é fundamental para o deslinde da questão (art. 85 da CF), como ensina Lênio Streck:

O impeachment, no modo como vem sendo praticado, é um arremedo, um álibi para transformar o presidencialismo em parlamentarismo. Exige-se crime - e isso é jurídico. Mas para dizer o que é esse 'jurídico', há liberdade absoluta para dizer qualquer coisa. É uma fraude linguística. Chama-se de jurídico aquilo que é, na prática, político ${ }^{83}$.

Ao contrário do que aconteceu na década de 1990, não se estava diante de irregularidades incontestáveis, sendo, por essa razão, essencial que houvesse uma maior divulgação sobre a materialidade do impeachment, qual seja, a manobra política que foi feita.

O viés político se tornou incontroverso na fala do Senador Acir Gurgacz, que logo após a votação dizia:

Foi uma decisão muito difícil mas importante para o nosso país. Eu entendo que não há crime de responsabilidade, mas falta governabilidade para a Presidente voltar a governar o nosso país. A volta da Presidente talvez causasse um problema ainda maior para a economia brasileira, que já não está bem ${ }^{84}$.

A imprensa estrangeira noticiou as diversas manobras no sentido de confundir-se o povo. Contudo, a imprensa brasileira, em caminho oposto, adotou a linha de apenas noticiar o cumprimento de normas formais.

\footnotetext{
${ }^{83}$ STRECK, Lenio Luiz. Processo Político-Jurídico. Disponível em: $<$ http://www.conjur.com.br/2016-ago-30/natureza-dupla-fragiliza-eficacia-impeachment-corrigirgovernos>. Acesso em: 01.05.2017.

${ }^{84}$ G1. Disponível em:

$<$ http://g1.globo.com/politica/processo-de-impeachment-de-dilma/noticia/2016/08/senador-votapelo-impeachment-mas-diz-que-nao-ha-crime-de-dilma.html>. Acesso em: 01.05.2017.
} 
O jornal inglês "The Guardian" lembrou que a primeira mulher a exercer o cargo de Presidente do Brasil foi tirada do poder "pelo Senado manchado de corrupção após um processo exaustivo" $" 85$.

O "El País", da Espanha, ressalta que a saída de Dilma não foi pela prática de crimes: "No fundo, o impeachment sempre foi político. Rousseff foi julgada (e condenada), entre outras coisas, por sua gestão" ${ }^{" 86}$.

O "New York Times", dos Estados Unidos da América, ao noticiar aduziu que todo impeachment é político, mas que o que ocorreu no Brasil foi algo mais sinistro ${ }^{87}$.

Contudo, a imprensa brasileira, reafirma-se, ao contrário da internacional, apenas noticiou os ritos cumpridos a partir dos mandamentos constitucionais, não expondo a motivação que estava por debaixo dos panos. Enquanto isso a imprensa internacional foi além e expressou o conteúdo real desse impedimento distorcido.

A formalidade não basta para os atos jurídicos, é preciso que haja materialidade nesses, sob pena de serem inconstitucionais, devendo isso ser abordado pelos grandes veículos de comunicação. Gilmar Mendes distingue formalismo e materialidade da seguinte forma:

\begin{abstract}
A inconstitucionalidade material envolve, porém, não só o contraste direto do ato legislativo com o parâmetro constitucional, mas também a aferição do desvio de poder ou do excesso de poder legislativo ${ }^{88}$.
\end{abstract}

No caso do impedimento da Presidenta Dilma, portanto, houve uma atuação omissiva da imprensa, que ao invés de promover uma

\footnotetext{
${ }^{85}$ VALOR. Disponível em:

$<$ http://www.valor.com.br/politica/4694901/imprensa-internacional-repercute-impeachment-dedilma>. Acesso em: 03.05.2017.

${ }^{86}$ EL PAIS. Disponível em:

<http://internacional.elpais.com/internacional/2016/08/31/america/1472649732_720732.html〉. Acesso em: 03.05.2017.

${ }^{87}$ NEW YORK TIMES. Disponível em:

<https://www.nytimes.com/2016/09/01/world/americas/brazil-impeachment-coup.html?_r=0>. Acesso em: 03.05.2017.

${ }^{88}$ MENDES, Gilmar Ferreira. Controle de constitucionalidade. In: BRANCO, P. G. G. et al.. Curso de Direito Constitucional. 5a ed. São Paulo: Saraiva, 2010.
} 
demonstração ampla do cenário que se apresentava, no qual uma manobra claramente política ocorria, optou apenas por noticiar os fatos de acordo com seus interesses de grupo, de maneira que não contribuiu em nada para o trâmite do processo sobretudo quanto ao seu dever de informação.

Os veículos de comunicação são livres para atuar da maneira que entenderem, não cabendo ao Executivo controlá-los. No entanto, existe um dever intrínseco a quem exerce este poder-dever, qual seja: de se posicionar diante dos fatos que circundam a sociedade, sem que isso fira o seu grau de imparcialidade.

A veiculação pela imprensa do que estava realmente ocorrendo talvez não impedisse o desfecho, mas poderia ter prejudicado menos a já frágil democracia brasileira.

\subsection{Da Cassação Do Mandato De Eduardo Cunha}

Eduardo Cunha é figura importante para a história política contemporânea brasileira, sobretudo no período que presidiu a Câmara dos Deputados. Não obstante, o foco desse último caso concreto analisado não será apenas em relação às atitudes que tomou durante o mandato parlamentar, mas também como foi a cobertura jornalística no contexto que envolveu seu mandato parlamentar.

O economista Eduardo Cunha se elegeu pela primeira vez Deputado Federal no ano de 2002, contando com o apoio de outro político fluminense que, de Prefeito de Campos dos Goytacazes a Governador do Estado do Rio de Janeiro, foi amealhando seguidores, Antony Garotinho, reelegendo-se em 2006, 2010 e 2014. Nesse último mandato, conseguiu o cargo de maior destaque até então, o de Presidente da Câmara dos Deputados.

Fez oposição forte ao Executivo, tentando pelos meios legais, atrapalhar o trâmite das demandas que o governo apresentava à Casa que presidia. Nesse contexto fazia algo que a Constituição lhe permitia e que 
quem votou nele poderia querer, pois não é papel de qualquer Casa Legislativa agradar o governo presidencialista, mas sim trabalhar com as suas convicções.

A partir dessas divergências exerceu papel central na articulação feita para que o impeachment da ex-Presidenta Dilma Rousseff se concretizasse.

Contudo, nesse período, diversas foram as irregularidades apontadas contra o Deputado, que, apesar de prestígio com os congressistas, não conseguia calar os que o acusavam.

Em agosto de 2015, o Deputado Eduardo Cunha foi denunciado pelo Procurador-Geral da República, Rodrigo Janot, que o acusou no Supremo Tribunal Federal de envolvimento em um esquema de corrupção ${ }^{89}$.

Com base no princípio da presunção da inocência não se esperava que nenhuma atitude fosse tomada, podendo o congressista permanecer no exercício de suas funções, até mesmo porque isso não fazia parte dos pedidos feitos. Até esse momento não poderia o Supremo tê-lo afastado de suas funções, sobretudo pautando-se no princípio da inércia e da falta de pedido para tanto.

Diante dessas e outras ilegalidades que eram atribuídas a Eduardo Cunha, foi aberto processo no Conselho de Ética contra o Deputado em novembro de 2015.

Contudo, em dezembro de 2015 Rodrigo Janot fez um pedido de natureza cautelar para que Eduardo Cunha fosse afastado da Presidência da Câmara dos Deputados ${ }^{90}$, por conta dos indícios de corrupção cada vez mais fortes:

\footnotetext{
${ }^{89}$ G1. Disponível em:

<http://g1.globo.com/politica/operacao-lava-jato/noticia/2015/08/procurador-janot-denunciaeduardo-cunha-ao-stf-por-corrupcao.html>. Acesso em: 10.05.2017.

${ }^{90}$ G1. Disponível em:

<http://g1.globo.com/politica/noticia/2015/12/pgr-pede-afastamento-de-eduardo-cunha-dapresidencia-da-camara.html $>$. Acesso em: 10.05.2017.
} 
A reiteração criminosa e o uso do cargo de representante do povo para atender interesses ilícitos e escusos, não apenas dos empresários, mas também próprios, é fator que demonstra a necessidade também do afastamento do cargo para evitar a reiteração criminosa, assegurando-se a ordem pública ${ }^{91}$.

As medidas cautelares têm o intuito de resguardar situações jurídicas, para que as mesmas não sejam prejudicadas, conforme lição de Humberto Theodoro Junior:

se existe um processo cautelar, como forma de exercício de jurisdição, existe, também, uma ação cautelar", que é considerado pela doutrina tradicional, com fulcro no artigo $5^{\circ}, \mathrm{XXXV}$, da Constituição Federal, como o direito público subjetivo autônomo e abstrato de provocar o órgão judicial a tomar providências que "conservem e assegurem os elementos do processo principal (pessoas, provas e bens), eliminando a ameaça de perigo ou prejuízo iminente e irreparável ao interesse tutelado no processo principal ${ }^{92}$.

Dessa forma, o relator do caso, Ministro Teori Zavascki, deveria ter apreciado com certa urgência o pedido, tendo em vista que se tratava do ocupante de um dos cargos de mais importantes na organização do estado brasileiro, que, naquele momento era pessoa suspeita de irregularidades.

Rodrigo Janot se refere a isso em seu pedido com as seguintes palavras:

Certamente referido cargo (presidência da Câmara) lhe dá muito maiores poderes para atender aos interesses espúrios dos empresários, pois é o Presidente da Câmara o responsável por estabelecer a pauta de votação da Casa e, ainda, interferir na escolha de diversos cargos estratégicos para tais votações.

Mesmo assim o tempo passou, a cautelar requerida pelo Procurador não foi concedida de pronto e o Deputado permaneceu no exercício de suas funções, presidindo a Câmara durante o processo de impeachment e também liderando os trabalhos da Casa em diversas votações. Além das demais votações existentes.

\footnotetext{
${ }^{91}$ ESTADÃO. Disponível em:

<http://politica.estadao.com.br/blogs/fausto-macedo/wpcontent/uploads/sites/41/2016/04/download-1461233969249.pdf>. Acesso em: 10.05.2017.

92 THEODORO JR. Humberto. Curso de direito processual civil - processo de execução e cumprimento de sentença, processo cautelar e tutela de urgência. v. II. 2007. p. 540.
} 
Apenas no dia 05 de maio de 2016 o relator, Ministro Teori Zavascki, afastou o réu do processo da função de Deputado Federal e, por consequência, da função de Presidente da Câmara dos Deputados.

Na decisão o ministro afirma que: "Além de representar risco para as investigações penais sediadas neste Supremo Tribunal Federal, é um pejorativo que conspira contra a própria dignidade da instituição por ele liderada".

Teori Zavascki reforça sua afirmação: (Eduardo Cunha) "não tem condições pessoais mínimas" para ser Presidente da Câmara pois "não se qualifica" para eventualmente substituir o Presidente da República ${ }^{93}$.

Após tentativas de anulação, o Conselho de Ética da Câmara dos Deputados votou pela cassação e o plenário confirmou esse entendimento, cassando o mandato de Eduardo Cunha, que posteriormente viria a ser preso provisoriamente por ordem judicial ${ }^{949596}$.

O problema todo nessa questão, ao contrário do que afirmam alguns, com o argumento de que Constituição não teria previsto isso, não é a interferência do Supremo Tribunal Federal no Poder Legislativo.

Este pensamento não pode preponderar, pois a falta de decoro por abuso de prerrogativas é uma das hipóteses de perda do mandato previstas no artigo 55, II e parágrafos $1^{\circ}$ e $2^{\circ}$, da Constituição. O Supremo pode julgar o deputado que cometeu um crime ${ }^{97}$, bem como poderia uma medida cautelar que garantisse o devido processo legal, especialmente em um caso no qual o réu estava abusando das prerrogativas do cargo para se beneficiar a atrapalhar as investigações.

\footnotetext{
${ }_{93}$ G1. Disponível em:<http://estaticog1.globo.com/2016/05/05/AC4070.pdf>. Acesso em: 15.05.2017.

${ }^{94}$ G1. Disponível em: <http://g1.globo.com/politica/noticia/2016/05/entenda-o-passo-passo-doprocesso-contra-cunha-na-camara.html>. Acesso em: 15.05.2017.

95 G1. Disponível em: <http://g1.globo.com/politica/noticia/2016/09/camara-cassa-mandato-deeduardo-cunha-por-450-votos-10.html>. Acesso em: 15.05.2017.

${ }^{96}$ G1. Disponível em: <http://g1.globo.com/pr/parana/noticia/2016/10/juiz-federal-sergio-morodetermina-prisao-de-eduardo-cunha.html>. Acesso em: 15.05.2017.

${ }^{97}$ Constituição da República Federativa do Brasil, artigo 53, parágrafo $1^{\circ}$.

BRASIL. Constituição (1988). Acesso em: 15.05.2017.
} 
Nas palavras de Lênio Streck:

(...) é possível afirmar que o afastamento de Cunha só teria sentido no momento do recebimento da denúncia, em dezembro, uma vez estando, na hipótese, presentes requisitos para isso. De novo: afastamento cautelar não é medida punitiva, não está sequer sujeita do mesmo modo ao regime das punições. É medida processual, para garantir o processo e não se confunde com o mérito ${ }^{98}$.

Por essas razões o relator agiu certo em afastar Eduardo Cunha, pois não passava perto do razoável que alguém com tantas irregularidades apontadas contra si se mantivesse no cargo. O que causa espanto é o fato de que a cautelar tenha sido julgada quase seis meses após seu pedido.

Ora, esses fatos já estavam nos autos e pela função que Eduardo Cunha exercia, era fundamental que fosse julgado rápido. Ainda que não fosse para afastá-lo, era importante haver um posicionamento, pois as atitudes que teve nesse período ficam no mínimo sob suspeita.

Vamos, então, nos ater nesse momento ao que fez a imprensa, ou melhor, ao que não fez. Diante de tantas irregularidades, houve divulgação até porque seria inimaginável que não houvesse. Porém nesse longo período de tempo até que fosse julgado, em momento algum repercutiu-se a demora ou sua legitimidade para ocupar cargo de tamanha importância na organização do Estado brasileiro.

A duração razoável do processo é um princípio consagrado na Constituição ${ }^{99}$, inserido por meio da Emenda Constitucional $\mathrm{n}^{\circ} 45$, e como tal deve ser respeitado, ao contrário do que ocorreu no caso, especialmente por conta do que Eduardo Cunha representava na organização de Estado.

A imprensa, diante do seu dever de fiscalização, deveria ter ao menos exigido explicações do Ministro sobre porquê não havia julgado o processo nesse período. Ressalte-se que os grandes veículos de informação agiram durante todo o período sem levantar qualquer questionamento.

\footnotetext{
${ }^{98}$ STRECK, Lenio Luiz. Direito Vs. Moral . Disponível em: <http://www.conjur.com.br/2016mai-08/streck-supremo-usar-excepcionalidade-julgar-cunha>. Acesso em: 15.05.2017.

99 Constituição da República Federativa do Brasil, artigo 5º LXXVIII.

BRASIL. Constituição (1988). Acesso em: 15.05.2017.
} 
Enquanto a decisão publicada em maio não saía, Eduardo Cunha realizou diversos atos fundamentais para a história contemporânea brasileira, sem que jamais fosse questionado se tais atos valeriam tendo em vista haver um pedido para seu afastamento.

Segundo Lênio Streck, tem que se questionar essa demora para julgar:

(...) como explicar que uma liminar (cautelar) é dada cinco meses depois de ser pedida pelo procurador-geral da República? Se tinha urgência, já não deveria ter sido apreciada? Para negar ou conceder. Pior: se Eduardo Cunha não tem atributos morais - hoje - para ser o presidente da Câmara e ser o eventual substituto de Temer, tinha ele condições de presidir o impeachment? E de presidir a Câmara enquanto seu processo na Comissão de Ética está (ou esteve) emperrado justamente nesses cinco meses? Existe imoralidade com efeito só para frente (ex nunc)? Até o dia 5 Eduardo Cunha era digno? Ficou indigno dia 5 em diante? Literalmente, da noite para o dia? A indignidade depende de uma nominação do STF? Uma espécie de "imoralidade imputacional"100.

Seria fundamental que a imprensa mais uma vez não tivesse se omitido, pois poderia ter mudado o rumo de diversas coisas que ocorreram sob a Presidência de Eduardo Cunha.

Caso fosse noticiado após o primeiro, o segundo, o terceiro, o quarto, ou o quinto mês que o relator do caso não julgava, talvez nascesse ou crescesse uma dúvida na própria população. Todos se perguntariam se era legitimo o Presidente de uma Casa Legislativa ter tantas acusações contra si e ainda assim ocupar cargo de tamanha importância.

A decretação do impeachment ocorreu na mesma época e a imprensa noticiava com um destaque maior os fatos ligados ao afastamento da Presidente da República sem questionar, além da materialidade do mesmo, quais os interesses por trás de quem presidia.

O jornalista não apenas noticia, mas também possui o dever se levantar questões de relevante interesse social para que toda coletividade discuta em conjunto os rumos tomados. Novamente, isso não foi feito,

100 STRECK. Disponível em: <http://www.conjur.com.br/2016-mai-08/streck-supremo-usarexcepcionalidade-julgar-cunha>. Acesso em: 15.05.2017. 
acarretando prejuízos que não podem ser estimados e cujas consequências são vistas por quem quiser. 


\title{
CAPÍTULO 4 - DA INFLUÊNCIA DA MIDIA NA ORGANIZAÇÃO DO ESTADO
}

A organização do Estado imaginada pelo legislador deve ser cumprida, tendo em vista que é o meio para alcançar as metas expostas da Constituição. Nesse sentido, a Norma Magna de 1988 trouxe os mais diversos desejos, tais quais saúde, segurança, educação, desenvolvimento, igualdade, proteção ao individuo, suas liberdades, entre outros.

O papel dos poderes exposto no artigo $2^{\circ}$ seria viabilizar tais metas, tornando-as concretas a partir de seu trabalho diário. Cada um dentro das competências previstas, respeitando-as de maneira que a interferência não seja além da medida proposta pela teoria dos freios e contrapesos, consoante a doutrina de Alexandre de Moraes:

\begin{abstract}
A divisão segundo o critério funcional é a célebre "separação de poderes", que consiste em distinguir três funções estatais, quais sejam, legislação, administração e jurisdição, que devem ser atribuídas a três órgão autônomos entre si, que as exercerão com exclusividade, foi esboçada pela primeira vez por Aristóteles, na obra "Política", detalhada posteriormente, por John Locke, no Segundo Tratado de Governo Civil, que também reconheceu três funções distintas, entre elas a executiva, consistente em aplicar a força pública no interno, para assegurar a ordem e o direito, e a federativa, consistente em manter relações com outros Estados, especialmente por meio de alianças. E, finalmente, consagrada na obra de Montesquieu O Espírito das Leis, a quem devemos a divisão e distribuição clássicas, tornando-se princípio fundamental da organização política liberal e transformando-se em dogma pelo art. 16 da Declaração dos Direitos do Homem e do Cidadão, de 1789, e é prevista no art. $2^{\circ}$ de nossa Constituição Federal ${ }^{101}$.
\end{abstract}

Esse cenário imaginado pelo constituinte nem sempre é cumprido, pois problemas sempre existirão, e apesar da previsão constitucional, harmonia nem sempre é o carro-chefe. Como em qualquer relação, divergências ocorreram tendo em vista que uma ação pode ser interpretada por um como um dever e por outro como uma invasão em sua esfera.

Isso faz parte de uma democracia, partindo-se sempre dos preceitos constitucionais de legalidade, razoabilidade e proporcionalidade. A partir 
do momento em que interesses que não sejam os da coletividade sobressaem, estamos diante de uma afronta não apenas à Constituição, mas à história brasileira que tanto sofreu até chegar a democratização.

Dentro desse contexto, surge o povo, soberano e detentor do poder maior dentro do Estado Democrático de Direito Brasileiro. Goffredo Telles Júnior ensina que

O que, em verdade, o axioma prenuncia é que o poder dos Governos, quando não emanado do povo, não é poder: é força, força armada; e, neste caso, o regime não tem o caráter de uma Democracia verdadeira. De acordo com o célebre princípio, o Governo em regime democrático, só é legitimo, quando seu poder emana do povo $^{102}$.

Contudo, em um país de dimensões continentais como o Brasil, para que todos efetivamente exerçam seu papel central na democracia, a informação se torna fundamental. É a partir dessa que as pessoas poderão ter consciência dos fatos, posturas e atos tomados por seus representantes.

A constatação de que o representante eleito está agindo de acordo com os parâmetros que fizeram o sujeito depositar sua confiança será realizada cotidianamente. Ainda que todos os atos sejam públicos e virem à todos pelos meios oficiais, esses não bastam para que se tenha real noção da situação fática.

Na sociedade contemporânea a mídia se tornou a principal fonte de notícia, sendo certo que é a partir dela que a maioria das pessoas molda sua opinião. Nesse contexto sua função ganha relevância para a vida das pessoas, tendo em vista que se trata de um direito fundamental.

Se tantas pessoas moldam suas opiniões a partir do que é vinculado na imprensa, é certo que um mal uso das prerrogativas dessa função prejudicará o juízo de valor de cada indivíduo.

102 TELLES JÚNIOR, Goffredo. O Povo e o Poder: O Conselho de Planejamento Nacional. São Paulo: Malheiros Editores, 2003. p. 70. 
Nesse tocante, devemos entender que esse prejuízo ocorre não apenas em relação à inverossimilhança dos fatos noticiados quanto a realidade deles, mas também envolve as lacunas deixadas por informações ainda imprecisas.

A violação desse direito é um abuso que toca diretamente na dignidade da pessoa humana. Um povo mal informado consequentemente será ignorante e facilmente manipulado.

A imprensa é o canal que promove a discussão entre os setores da sociedade. É por meio de seu papel bem feito que as informações se aproximam do povo e permitem que esse livremente monte sua opinião.

Quando isso não é feito, certos setores são beneficiados a partir do desconhecimento popular, muitas vezes por uma vontade da mídia de ditar certos rumos - tal qual ocorreu na disputa presidencial entre Fernando Collor de Mello e Luiz Inácio Lula da Silva.

Contudo, não basta que a imprensa noticie pura e simplesmente. É preciso que essa atue pensando em fornecer o melhor da informação, promovendo o debate e o contraditório, sempre dentro da liberdade que the é atribuída e, sem dúvidas, essencial para o bom exercício dessa atividade.

Em diversos momentos, o jornalismo informativo, o qual tem como função precípua levar ao povo o fato despido de valores, adjetivações ou de opinião individual, foi trocado pela mensagem dramática e envolvente, elegendo mocinhos e bandidos conforme sua conveniência.

A sociedade tem o direito de receber todos os lados de um fato, sendo certo que é papel da imprensa promover isso. Caso opte por expor mais um lado que outro, por certo estará ferindo dever inerente à essa atividade, bem como o interesse popular.

Ademais, o poder da mídia se encontra não só na construção da realidade, mas também em sua ocultação. Aqueles que podem difundir notícias em grande escala, também podem difundir silêncios. 
A atividade jornalística já auxiliou em grandes mudanças no cenário político brasileiro. Sob a ótica de análise do Brasil pós-democratização, ainda que em pouco tempo, a imprensa já participou ativamente na construção de fatos que serão lembrados ao longo da história.

Nesse sentido, corroborou para a derrocada de dois presidentes democraticamente eleitos. No entanto, com atuações distintas em cada caso. Enquanto em um investigou e mostrou as autoridades competentes, bem como ao povo, evidências de corrupção e menosprezo aos princípios constitucionais, em outro não promoveu o contraditório ou demonstrou a verdade dos interesses escondidos nas atitudes tomadas.

Em outra situação não relatou a demora judiciária em analisar uma denúncia grave de corrupção em relação à quem ocupava um dos cargos de maior importância da estrutura política brasileira, sendo certo que essa mesma pessoa cometia mandos e desmandos sem que houvesse qualquer questionamento quanto à sua legitimidade para ocupar tal cargo.

Não restam dúvidas de que em casos de corrupção ou má-fé de políticos, agentes públicos ou qualquer outro individuo, os grandes culpados são esses, que atuam por seus interesses próprios e não os da sociedade. Nesse sentido, não seria correto colocar o futuro da democracia nas mãos da imprensa, pois isso sem dúvida seria atribuir à essa uma relevância além da que lhe é reservada.

Porém, seria incorreta chamá-la de quarto poder, como alguns o fazem. Ainda que sua influência seja considerável, um juízo de comparação em relação aos demais poderes da República é excessivo. A constituição previu três poderes, e por certo esses são os únicos existentes a partir do modelo criado tempos atrás.

Não obstante, essa precisa realizar seu papel corretamente, pois suas funções afetam diretamente a estabilidade do país. Para que a soberania popular seja devidamente exercida sua atuação é imprescindível, apesar de 
eventos recentes demonstrarem que talvez essa não esteja tão comprometida com isso.

Os fundamentos da democracia estão cobertos pela manta dos princípios da igualdade e da liberdade. O exercício desses e outros princípios é essencial para a manutenção do Estado Democrático de Direito e sua estrutura.

Atualmente, a definição de liberdade e igualdade se relaciona amplamente com o de cidadania, de maneira que a democracia apenas será plena em uma sociedade de cidadania incondicional.

No entanto, essa cidadania necessita de uma grande participação popular para amadurecer, sobretudo em um país como o Brasil que experimento esse regime ainda há pouco tempo. Diante disso, ainda que o direito positivado seja o dominante, é preciso que se valorize preceitos nem sempre inscritos na norma.

A democracia participativa permite a inserção social dos menos abastados, sendo propiciada pela própria valorização dos direitos coletivos previstos constitucionalmente, sendo certo que nessa realidade a função da imprensa é indispensável. A participação de todos os setores da população é que torna o sistema de fato democrático, sendo certo que essa realidade ainda é distante da que se vive no Brasil. 


\section{CONCLUSÃO}

O trabalho teve objetivo de analisar o papel da imprensa na organização do Estado e a maneira como a mídia exerce seu papel dentro desse, auxiliando ou não no exercício diário da democracia, da mesma maneira que os demais setores da sociedade.

Inicialmente estruturamos o Estado, para a partir de comentários existentes na doutrina brasileira sobre o tema para entendermos como o constituinte originário pretendia organizar a estrutura de poder brasileira com o objetivo de alcançar o desenvolvimento social.

Os fins previstos na Constituição de 1988 eram novos em relação à realidade vivida pelos brasileiros na década de 1960 e 1970, no qual o controle estatal era excessivo e as liberdades eram mínimas, sendo certo que a censura, infelizmente, era palavra de ordem.

Nesse sentido, analisamos a maneira como os três poderes do Estado brasileiro se estruturam, suas atribuições características e as que não seriam típicas, mas válidas a partir do prisma das teorias dos freios e contrapesos.

No segundo capítulo passamos à análise do direito à informação. A escolha por este referencial se deu em função do papel da mídia na sociedade contemporânea, o qual, sem dúvida, é importantíssimo, sobretudo no intuito de fazer com que o povo seja informado e ciente dos atos e omissões de seus representantes.

Ademais, ressaltou-se a liberdade de expressão, garantia constitucional não apenas para os profissionais da imprensa, mas sim para toda a população. Contudo, esse exercício necessita de uma cautela maior nos tempos atuais, em que as pessoas se utilizam das redes sociais muitas vezes para exaltar discursos de ódio ou criar fatos inverídicos.

Destacamos também a liberdade de imprensa, essencial para a atividade jornalística. Essa em outros tempos foi suprimida pelos interesses 
governamentais que controlavam sua atividade, impedindo o exercício digno dos profissionais de imprensa.

A história deixa claro o valor da imprensa desde que surgiu, e em tempos modernos, nos quais as pessoas têm acesso à notícia assim que os fatos ocorrem, isso assume maior importância, mesmo que os informes fiquem restritos às breves linhas em que são expostos.

Neste contexto, a responsabilidade dos veículos de informação aumenta, pois o que se expõe em breves linhas para muitos será lido como verdade absoluta. Se por um lado isso nos faz ter mais notícias e conhecimentos em tempo real, nos torna também mais suscetíveis às manipulações.

Analisando esta face, tem-se que a imprensa vem atuando de maneira que merece a devida atenção, restando por evidente que o povo tem o direito de ser bem informado. Uma informação inverídica ou até mesmo imprecisa pode acarretar um falso juízo de valor, sendo por certo violador dos preceitos que todos os jornalistas devem seguir, consoante o código de ética desses profissionais.

A partir do terceiro capítulo restou clara a relevância da atividade jornalística na sociedade, importando em diversas consequências, tendo em vista o exame dos fatos ocorridos em eventos políticos recentes que alteraram a ordem instituída.

No caso Collor, depois de uma cobertura impecável dos jornalistas que descobriram condutas ilícitas praticadas pelo então Presidente, a consequência foi a decretação do impeachment. Nesse tocante, a atuação positiva da imprensa foi fundamental para o deslinde que culminou com o afastamentot do primeiro presidente eleito após o período de ditadura civilmilitar.

No segundo caso analisado tratamos do impeachment da exPresidenta Dilma, em que o debate e a exposição concreta dos fatos se 
mostrou ineficiente e superficial. A imprensa tem o dever de promover o debate e demonstrar o que de fato ocorre, sendo certo que nesse caso não levou ao público as razões espúrias que culminaram com a derrocada da Chefe do Executivo Federal.

Por fim, vimos o caso do ex-Deputado Eduardo Cunha, que foi afastado após seis meses do pedido de cautelar feito pelo Procurador-Geral da República, sem que houvesse qualquer questionamento em relação à demora ocorrida. Nesse ínterim, o então Congressista realizou diversos atos - inerentes ao cargo que ocupava - que mudaram o curso político brasileiro.

No último capítulo, afirmamos que a democracia depende de uma atuação de todos para que se concretize, pois qualquer fato deve ser amplamente noticiado, sobretudo aqueles em que a ordem política. Esse exercício é essencial para que o povo tenha conhecimento desses e possa agir, diante da liberdade que possui.

Contudo, se a população não estiver bem informada de tudo que ocorre, não haverá pelo que clamar ou ainda pior, estará sendo induzida a se posicionar de acordo com interesses ilegítimos. 


\section{REFERÊNCIAS BIBLIOGRÁFICAS}

ABRAMOVAY, Pedro. Separação de Poderes e Medidas Provisórias. Rio de Janeiro: Elsevier, 2012.

AGÊNCIA DE NOTÍCIAS DOS DIREITOS DA INFÂNCIA. Art. 19, 2009.

BARBOSA, Rui. A Imprensa e o Dever da Verdade. São Paulo: Editora da Universidade de São Paulo, 1990. Disponível em:

<http://www.casaruibarbosa.gov.br/interna.php?ID_S=105>. Acesso em: 09.02.2017.

BARROSO, Luís Roberto. Curso de Direito Constitucional Contemporâneo: os conceitos fundamentais e a construção do novo modelo. São Paulo: Saraiva, 2009.

O Direito Constitucional e a Efetividade de suas Normas: Limites e Possibilidades da Constituição Brasileira. $7^{\mathrm{a}}$ ed. São Paulo: Renovar, 2003.

BAUMAN, Zygmunt. Modernidade Líquida. DENTZIEN, Plínio (Trad.). Rio de Janeiro: Zahar, 2003. 258 p.

BONAVIDES, Paulo. Curso de Direito Constitucional. $15^{\mathrm{a}}$ ed. 2014. p. 138.

BRASIL. Câmara dos Deputados. Regimento Interno, estabelecido pela Resolução n. 17, de 1989. Art. 217. Disponível em:

<http://www2.camara.gov.br/legislacao/regimentointerno.html>. Acesso em: 01.05.2017.

BRASIL. Constituição (1988). Disponível em:

<http://www.planalto.gov.br/ccivil_03/constituicao/constituicao.htm>.

Acesso em: 20.09.2016.

BRASIL. Lei no 5.250, DE 9 DE FEVEREIRO DE 1967. Regula a liberdade de manifestação do pensamento e de informação. Disponível em: $<$ http://www.planalto.gov.br/ccivil_03/decreto-lei/1937-

1946/Del1608.htm>. Acesso em: 20.03.2017.

BRASIL. Lei $n^{\circ}$. 8.078, de 11 de setembro de 1990. Art. 6º III. Código de Defesa do Consumidor. Dispõe sobre a proteção do consumidor e dá outras 
providências. Disponível em:

<http://www.planalto.gov.br/ccivil_03/Leis/L8078.htm>. Acesso em: 08.01.2017.

CANOtIlHO, J. J. Gomes et al.. (Org.). Comentários à Constituição do Brasil. São Paulo: Saraiva/Almedina, 2013.

CARVALHO, Luiz Gustavo Grandinetti Castanho de. Direito de Informação e Liberdade de Expressão. Rio de Janeiro: Renovar, 1999.

CHOMSKY, Noam. Mídia, propaganda política e manipulação. SANTOS, Fernando (Trad.). São Paulo: WMF Martins Fontes, 2013.

DATAFOLHA. Disponível em:

$<$ http://datafolha.folha.uol.com.br/opiniaopublica/2013/06/1297630-redesocial-e-imprensa-tem-maior-prestigio-e-poder-na-sociedade-brasileiradizem-paulistanos.shtml/>. Acesso em: 10.12.2016.

Declaração dos Direitos do Homem e do Cidadão. art. 4. França, 1789. Disponível em: < http://pfdc.pgr.mpf.mp.br/atuacao-e-conteudos-deapoio/legislacao/direitos-humanos/declar_dir_homem_cidadao.pdf >. Acesso em: 01.12.2016.

Disponível em: <https://www.youtube.com/watch?v=VrpurEkmJkU>. Acesso em: 01.04.2017.

EL PAIS. Disponível em:

$<$ http://internacional.elpais.com/internacional/2016/08/31/america/1472649 732_720732.html>. Acesso em: 03.05.2017.

ESTADÃO. Disponível em:

$<$ http://politica.estadao.com.br/noticias/geral,para-mp-pedaladas-dogoverno-dilma-nao-sao-crime,10000062862>. Acesso em: 01.05.2017.

Disponível em:

<http://acervo.estadao.com.br/noticias/topicos,impeachment-decollor,887,0.htm>. Acesso em: 20.04.2017.

Disponível em: <http://politica.estadao.com.br/blogs/faustomacedo/wp-content/uploads/sites/41/2016/04/download1461233969249.pdf>. Acesso em: 10.05.2017.

FENAJ. Disponível em: <http://fenaj.org.br/legislacaoprofissional/juridica/>. Acesso em: 20.03.2017. 
FERNANDES, Bernardo Gonçalves. Curso de Direito Constitucional. $3^{\mathrm{a}}$ ed. Rio de Janeiro: Lumen Juris, 2011.

FOLHA DE S. PAULO.Disponível em: <http://www1.folha.uol.com.br/poder/2015/10/1698480-a-exemplo-dedilma-estados-tambem-fizeram-manobras-fiscais-em-2014.shtml>. Acesso em: 01.05.2017.

FOLHA DE S. PAULO. Disponível em:

Disponível em:

<http://politica.estadao.com.br/noticias/geral,votacao-fatiada-deimpeachment-e-no-minimo-bizarro-diz-gilmar-mendes, 10000073485

Disponível em:

<http://www1.folha.uol.com.br/especial/2015/brasil-em-crise/oimpeachment-de-dilma/\#como-tudo-comecou>. Acesso em: 01.05.2017.

. Disponível em: <http://www1.folha.uol.com.br/colunas/lauracarvalho/2016/10/1820312-para-enfrentar-a-crise-temer-aumenta-gastoscom-publicidade.shtml>. Acesso em: 08.01.2017.

.Disponível

em:

http://painel.blogfolha.uol.com.br/2016/03/31/plano-para-salvar-dilmarousseff-passa-por-inflar-ministerios-de-pp-pr-e-psd-ate-ptn-recebeuoferta/>. Acesso em: 01.05.2017.

FOLHAPRESS. Folha de São Paulo. "Impeachment". 29/9/1992:1. Disponível em:

<http://www.snh2015.anpuh.org/resources/anais/39/1443808918_ARQUIV O_Vinicius_Franca.pdf $>$. Acesso em: 20.04.2017.

GAZETA DO POVO. Disponível em:

$<$ http://www.gazetadopovo.com.br/vida-publica/especiais/impeachment-20anos/um-presidente-feito-e-desfeito-pela-imprensa-

2zd0gilpep3bxuw32brc3fd5a>. Acesso em: 01.04.2017.

G1. Disponível em:

<http://estaticog1.globo.com/2016/05/05/AC4070.pdf>. Acesso em: 15.05.2017.

G1. Disponível em: <http://g1.globo.com/politica/noticia/2016/05/entendao-passo-passo-do-processo-contra-cunha-na-camara.html>. Acesso em: 15.05.2017. 
G1. Disponível em: <http://g1.globo.com/politica/noticia/2016/09/camaracassa-mandato-de-eduardo-cunha-por-450-votos-10.html>. Acesso em: 15.05.2017.

G1.Disponível em: <http://g1.globo.com/politica/processo-deimpeachment-de-dilma/noticia/2016/08/senador-vota-pelo-impeachmentmas-diz-que-nao-ha-crime-de-dilma.html>. Acesso em: 01.05.2017.

G1. Disponível em: <http://g1.globo.com/pr/parana/noticia/2016/10/juizfederal-sergio-moro-determina-prisao-de-eduardo-cunha.html >. Acesso em: 15.05.2017.

G1. Disponível em: <http://g1.globo.com/politica/noticia/2015/12/leiaintegra-da-carta-enviada-pelo-vice-michel-temer-dilma.html>. Acesso em: 01.05.2017.

G1. Disponível em: <http://g1.globo.com/politica/noticia/2015/12/pgrpede-afastamento-de-eduardo-cunha-da-presidencia-da-camara.html $>$. Acesso em: 10.05.2017.

G1. Disponível em: <http://g1.globo.com/politica/noticia/2016/03/68apoiam-impeachment-de-dilma-diz-pesquisa-datafolha.html>. Acesso em: 01.05.2017.

G1. Disponível em: <http://g1.globo.com/politica/operacao-lavajato/noticia/2015/08/procurador-janot-denuncia-eduardo-cunha-ao-stf-porcorrupcao.html>. Acesso em: 10.05.2017.

GLOBO. Disponível em: <http://memoriaglobo.globo.com/programas/jornalismo/coberturas/impeach ment-de-collor/o-relatorio-final-da-cpi.htm>. Acesso em: 20.04.2017.

GLOBO. Disponível em:

<http://memoriaglobo.globo.com/programas/jornalismo/coberturas/eleicoes -presidenciais-1989/o-segundo-turno.htm>. Acesso em: 01.04.2017.

ISTOE. Disponível em: <http://istoe.com.br/161904_DEPOIMENTO+DE+MOTORISTA+LEVA+ AO+IMPEACHMENT+DO+PRESIDENTE > . Acesso em: 20.04.2017.

LEITE, Fábio Carvalho. Liberdade de Expressão e Direito à Honra: Novas Diretrizes para um Velho Problema. In: CLÈVE, Clèmerson Merlin; FREIRE, Alexandre (Org.). Direitos fundamentais e Jurisdição 
Constitucional: Análise, Crítica e Contribuições. $1^{\mathrm{a}}$ ed. São Paulo: Revista dos Tribunais, 2014.

MELLO, Celso Antônio Bandeira de. Curso de Direito Administrativo. $20^{a}$ ed. São Paulo-SP: Editora Malheiros, 2006.

MENDES, Gilmar Ferreira. Controle de constitucionalidade. In: BRANCO, P. G. G. et al.. Curso de Direito Constitucional. $5^{\text {a }}$ ed. São Paulo: Saraiva, 2010 .

. Curso de Direito Constitucional. São Paulo: Saraiva, 2007.

MORAES, Alexandre de. Direito Constitucional. 21 a ed. São Paulo: Atlas, 2007.

NEW YORK TIMES. Disponível em:

<https://www.nytimes.com/2016/09/01/world/americas/brazilimpeachment-coup.html?_r=0>. Acesso em: 03.05.2017.

SALGADO, Eneida Desirre. Princípios Constitucionais Eleitorais. Belo Horizonte: Fórum, 2010.

SALOMÃO, Paulo César. O Confronto entre o Direito à Intimidade e o Direito à Informação. Revista de Direito do Tribunal de Justiça do Estado do Rio de Janeiro. Rio de Janeiro. n. 66. 2006.

SARLET, Ingo Wolfgang. A eficácia dos direitos fundamentais. $6^{\mathrm{a}}$ ed. Porto Alegre: Livraria do Advogado, 2006.

SENADO. Disponível em:

<http://www 12.senado.leg.br/noticias/materias/2008/08/08/jose-afonso-dasilva-o-mais-dramatico-na-constituinte-foi-a-rebeliao-dos-conservadores $>$. Acesso em: 17.09.2016.

SILVA, José Afonso da. Curso de Direito Constitucional Positivo. $22^{\mathrm{a}}$ ed. São Paulo: Malheiros, 2003.

- Curso de Direito Constitucional Positivo. $11^{\mathrm{a}}$ ed. : São Paulo Malheiros Editores, 2002.

Curso de Direito Constitucional Positivo. $16^{\mathrm{a}}$ ed. rev. atual. São Paulo: Malheiros, 1998. 
Curso de Direito Constitucional Positivo. $20^{\mathrm{a}}$ ed. São Paulo: Malheiros, 2001.

SOUSA, Nuno e. A liberdade de imprensa. Coimbra: Coimbra, 1984. p.

STF. ADPF 130. Relator Ministro Carlos Ayres Britto. Brasília, 30 de abril de 2009.

STF. Disponível em:

<http://www.stf.jus.br/portal/cms/vernoticiadetalhe.asp?idconteudo $=10740$

2>. Acesso em: 20.03.2017.

STF. MEDIDA CAUTELAR NA RECLAMAÇÃO 22.328. Relator Ministro: Luís Roberto Barroso. 20 de Novembro de 2015.

STRECK, Lenio Luiz. Jurisdição Constitucional e Decisão jurídica. $3^{\mathrm{a}}$ ed. São Paulo: Revista dos Tribunais, 2013.

PROCESSO POLÍTICO-JURÍDICO. Disponível em:

$<$ http://www.conjur.com.br/2016-ago-30/natureza-dupla-fragiliza-eficaciaimpeachment-corrigir-governos >. Acesso em: 01.05.2017.

Direito Vs. Moral . Disponível em:

<http://www.conjur.com.br/2016-mai-08/streck-supremo-usarexcepcionalidade-julgar-cunha>. Acesso em: 15.05.2017 e 25.05.2017.

TELleS JÚNIOR, Goffredo. O Povo e o Poder: O Conselho de Planejamento Nacional. São Paulo: Malheiros Editores, 2003.

THEODORO JR. Humberto. Curso de direito processual civil - processo de execução e cumprimento de sentença, processo cautelar e tutela de urgência. v. II. 2017.

VALOR. Disponível em:

<http://www.valor.com.br/politica/4694901/imprensa-internacionalrepercute-impeachment-de-dilma>. Acesso em: 03.05.2017.

VEJA. Disponível em: <http://veja.abril.com.br/blog/reinaldo/aentrevista-que-pedro-concedeu-a-veja-ha-20-anos-e-que-esta-na-raiz-doodio-que-fernando-collor-tem-da-revista/>. Acesso em: 01.04.2017. 